\title{
Комплексное палеоантропологическое и палеопатологическое исследование останков из памятника Ованнаванк
}

\author{
Н.Г. Акопян, А.С. Жамкочян, А.Ю. Худавердян \\ Институт археологии и этнографии Национальной Академии наук Республики Армения, \\ Республика Армения, 0025, Ереван, ул. Чаренци, 15
}

\begin{abstract}
Аннотация: Целью статьи является изучение скелетных останков девяти индивидов (три мужчины, три женщины, три ребенка), обнаруженных в августе 2015 г. во время раскопок средневекового монастырского комплекса Ованнаванк в Армении. Впервые для этого могильника получен комплексный палеоантропологический анализ данных. У индивидов Ованнаванка (NN 1, $2,3,4,5)$ обнаружены искусственные деформации головы. В них наблюдается деформация двух типов: кольцевая лобно-затылочная башанного типа и кольцевая лобно-затылочная, приближающая по форме к конусу. Выявлены следы патологических процессов на скелетах и реконструирована их этиология. У индивидов выявлен комплекс морфологических признаков, характерных для кавкасионского типа.
\end{abstract}

Ключевые слова: Армения, Ованнаванк, средневековье, краниология, краниоскопия, одонтология, кавкасионский тип, палеопатология.

Для цитирования: Акопян Н.Г., Жамкочян А.С., Худавердян А.Ю. 2021. Комплексное палеоантропологическое и палеопатологическое исследование останков из памятника Ованнаванк. Via in tempore. История. Политология, 48 (1): 65-96. DOI: 10.52575/2687-0967-2021-48-1-65-96.

\section{Comprehensive paleoanthropological and paleopatological research of the remains from Hovhannavank monument}

\author{
Nyura G. Hakopyan, Agavni S. Zhamkochyan, Anahit Yu. Khudaverdyan \\ Institute of Archaeology and Ethnography of National Academy of Science of Republic of Armenia, \\ 15 Charenci St., Yerevan, 0025, Republic of Armenia \\ akhudaverdyan@mail.ru
}

\begin{abstract}
The material of the study was the skeletal remains of 9 individuals (three men, three women, and three children) discovered in 2015 during excavations of Hovhannavank. Hovhannavank is one of the medieval monastic complexes of Armenia. For the first time, a comprehensive paleoanthropological analysis of the data was obtained for this grave. At the Hovhannavank individuals (№№ 1, 2, 3, 4, 5), accurate traces of deliberate deformation of the head are noted. Basing on anthropological and paleopathological data, two types of deformation were observed: circular high (high ring) and low. Traces of pathological processes on skeletons have been revealed and their etiology has been reconstructed. The complex of morphological signs, characteristic for the Caucasian type, is revealed. Among the inhabitants of Hovhannavank in the late Middle Ages, there are specific complexes of features that, judging by the craniological data available today, are not characteristic of the Armenian population of earlier eras. This complex of features is close to the Caucasian type.
\end{abstract}

Key words: Armenia, Hovannavank, Middle Ages, craniology, cranioscopy, odontology, Caucasian type, paleopathology.

For citation: Hakopyan N.G., Zhamkochyan A.S., Khudaverdyan A.Yu. 2021. Comprehensive paleoanthropological and paleopatological research of the remains from Hovhannavank monument. Via in tempore. History and political science, 48 (1): 65-96 (in Russian). DOI: 10.52575/2687-0967-2021-48-1-65-96. 
Ованнаванк - один из важнейших средневековых монастырских комплексов Армении, расположенный на краю скалистого обрыва ущелья реки Касах, напротив горы Араилер (2 600 м), в Арагацотнской области (рис. 1). Ованнаванк окружен с трех сторон мощной и протяженной стеной, а с четвертой стороны защищен природной преградой, склонами Касаха [Кафадарян, 1948, с. 42].

Ованнавак состоит из двух церквей: однонефной сводчатой базилики и одной церкви с просторным притвором-часовней на западной стороне. Согласно преданию, благодаря содействию царя Трдата Григорий Просветитель основал базиликальную церковь в начале IV в., разместив там святые мощи Иоанна Предтечи и освятив священную постройку. Базилика в честь св. мощей Иоанна Предтечи была названа именем св. Карапета. Однонефная базилика по своим планировочным пропорциям построена самое позднее в начале V в., а вопрос более ранней датировки должен быть еще выяснен [Тораманян, 1948 , c. 131].

Посетивший монастырь немецкий путешественник и ученый Мориц Вагнер (1-я пол. XIX в.) пишет: «При обозрении глубокого ущелья со склонов Арагаца открывается высшей степени живописная и великолепная панорама. Через ущелье протекает река Апаран (Касах). Этим захватывающим дух зрелищем можно наслаждаться с территории монастыря св. Ованнаванк» [Шахазиз, 1987, с. 303].

Монастырь Ованнаванк является шедевром армянской архитектуры XIII в. благодаря своему величию, притвору, изящным скульптурам и рациональным архитектурным решениям [Тораманян, 1948, с. 55]. Ованнаванк был не только комплексом действующих церквей, но и известной обителью: «Так, под покровительством Святого Карапета среди многочисленных братьев-отшельников была написана и отдана сему святому братству эта услаждающая [душу] история на помин души его» [Канакерци, 1870, с. 5-6]. В 1243 г. Курд Вачутян перенес епархиальный епископский престол Арагацотна из крепости Амберд в Ованнаванк [Манучарян, 2019, с. 98].

О реставрационных работах и изменениях монастыря Ованнаванк писал также Гарегин Овсепян: «Нынешнее здание Ованнаванка является творением XIII в. В его северной части, однако, есть однонефная церковь, некоторые признаки которой указывают на то, что она является постройкой, основанной до VII в. Церковь была отреставрирована неоднократно, но при этом сохранила древнейшие элементы, такие как полуколонны по обеим сторонам входа и остатки подковообразной арки внутри, которые характерны для наших древних и базиликальных церквей. Ованнаванк упоминается в документах 603-606 гг. и современных источниках. Также древние корни имеет то предание, что она была построена рукой Григория Просветителя в начале IV в.» [Овсепян, 1944, с. 20].

Следующая и основательная реконструкция базилики была произведена в 1652 г. настоятелем Захарией Вагаршапатеци [Даврижеци, 1891, с. 268]. Однако церкви св. Карапета не было суждено долго оставаться неповреждённой. Вследствие разрушительного землетрясения 1679 г. она была снова разрушена: «.... В Святой обители Ованнаванка рухнули все красивые жилища, обрушилась церковь, и мы с трудом избежали смерти», - с большой горечью и грустью отзывается Диакон Закария (Канакерци) [Канакерци, 1870, c. 104]. Архитектурная планировка церкви св. Карапета простая, без элементов орнаментации, за исключением фресок 2-й пол. XIX в.

В Ованнаванке на тимпане западного портала кафедрального собора находится барельеф с изображением притчи о разумных и неразумных девах. Появление изображения этой притчи на тимпане церкви необычно для армянского искусства, хотя традиция украшения тимпанов церквей в XIII-XIV вв. широко была распространена в Армении, однако скульптурное воплощение этой притчи среди армянских памятников нашло место лишь в Ованнаванке [Закарян, 1973, с. 294]. В центре изображена фигура сидящего на троне Христа. Его правая рука поднята над головами разумных дев, указывая на их праведные дея- 
ния. Изображения пяти разумных дев расположены друг за другом с поднятыми свечами, в то время как неразумные стоят словно отвергнутые, с поникшими головами.

Постройка церкви Катогике началась в 1216 г. согласно надписи на западной стене северо-восточной ризницы. «Волею благодетельного Господа, во время властвования сына Закаре, великого Шахншаха и правления сына Ваче, кусакала ${ }^{22}$ амир Курда в нашей провинции (Арагацотн), в 1221 г. я, Аствацатур вардапет, при содействии членов монастырской братии и как духовное дитя вардапета Акопоса, предпринял сторительство чудесно украшенной церкви Катогике». Это означает, что постройка церкви Катогике продолжалась шесть лет, с 1216 по 1221 гг. Церковь сохранилась до 1918 г., когда она пострадала из-за землетрясения. Она была полностью отреставрирована в 90-е гг. прошлого столетия.

Церковь-притвор. Эта постройка характерна для архитектуры XIII в. В центральной части находится большой зал, купол, опирающийся на четыре колонны, а в центре купола - округлое отверстие. На куполе возвышается колокольня с двенадцатью колоннами. Четыре колонны церкви соединяются со стенами посредством высокопролетных арок, возвышающихся над пилонами. Притвор, согласно преобладающему мнению, был построен сыном Ваче, князем Курдом. Постройка началась в 699 г. (1247 или 1248) по армянскому летоисчислению, а была окончена в 700 г., т. е. в 1251 г. [Кафадарян, 1948, c. 39]. Притвор примечателен исключительным богатым внутренним убранством: украшенными рельефным орнаментом хачкарами, фресками, ажурной растительной и геометрической орнаментацией. Притвор служил в качестве усыпальницы, где покоились представители высшего духовенства и настоятели монастыря, князья и члены княжеской семьи. «Сам князь Курд, - как пишет Закария Канакерци, - оставив мирскую славу, удалился на остров Севан, облачился в одеяние отшельника, стал священнослужителем, умер там и был захоронен в притворе церкви» [Канакерци, 1969, с. 218].

Kpenocmные стены. Надпись о постройке крепостной стены была найдена к северу от монастырского комплекса, на пьедестале одного хачкара на кладбище. Хачкар не сохранился, но до нас дошла интерпретация Закарии Канакерци. Надпись свидетельствует о том, что крепостная стена была построена безвременно скончавшейся женой царя Абгара Кюрикяна, Наной, либо, согласно надписи санаинского моста, благодаря средствам Ванени [Орбели, 1915]. К. Кафадарян считает, что постройку крепостной стены и моста Нана начала после смерти мужа (1192 г.), следовательно, в 1190-е гг. или же в начале XIII в. [Кафадарян, 1948, с. 43]. Крепостная стена построена из местной твердой горной породы кубической формы. В более удовлетворительном состоянии сохранились южная и северная стены. В одном из колофонов мы читаем: «Внути древних крепостных стен, с южной стороны церкви были построены хозяйственное помещение, трапезная и кельи» [Алишан, 1890, c. 173].

Работы по очистке, а затем и раскопки были предпринятны в июле-августе 2015 г. у северной стены (с внешней стороны) базиликальной церкви. Территория была покрыта скоплениями земли и строительного мусора. Во время удаления слоя земли на глубине около метра были открыты ямы винодавильни и костные останки 9 индивидов. Ранее, во время очистки земляных насыпей, непосредственно под стеной были открыты несколько крупных карасов (пифосов) для вина. При монастыре находились гостевой дом, резиденция главы епархии, библиотека, школа и иные хозяйственные постройки, которые находятся в разрушенном состоянии. Сохранившиеся руины относятся предположительно ко времени Закарии Канакерци. Диакон Закария (Канакерци) и Ерванд Шахазиз свидетельствуют, что при монастыре действовала общеизвестная школа, с высокопоставленными раввинами и лекторами. Раскопки выявили не только целостную картину архитектурной планировки монастыря, но и малочисленный, но информативный ассортимент глазиро-

${ }^{22}$ Кусакал - начальник области или страны в средневековой Армении. 
ванной и неглазированной керамики. Коллекцию дополнили также фрагменты фаянсовых столовых сосудов. Вышеупомянутые образцы глазированной и фаянсовой столовой посуды были импортированы из соседнего Ирана. Предположительно данная посуда могла быть использована для угощения гостей монастыря, которые с большой охотой отдыхали в стенах мирной обители. Отшельники монастыря и ученики монастырской школы жили тихой и скромной жизнью, которая диктовалась аскетическим образом жизни монахов.

Извлеченный из раскопок 2015 г. костный материал изучался по хорошо известным антропологическим методикам [Алексеев, Дебец, 1964, с. 52; Зубов, 1968а, с. 10, 1968б, c. 139; Buikstra, Ubelaker, 1994, p. 17]. Все черепа визуально обследованы на предмет наличия прижизненных повреждений, следов заболеваний и некоторых генетически наследуемых признаков [Мовсесян, Мамонова, Рычков, 1975, с. 129; Ortner, Putschar, 1981; Goodman et al., 1984, p. 13-49; Goodman, Armelagos, 1989, p. 225-243; Aufderheide, Rodriguez-Martin, 1998; Ortner, 2003].

Индивид № 1. Останки принадлежат женщине, биологический возраст которой определяется в пределах 45-55 лет. Останки характеризуются общей грацильностью строения, с очень слабо выраженным рельефом в области надбровья. У индивида наблюдаются искусственная лобно-затылочная деформация и асимметрия черепа (плагиоцефалия, plagiocephalia) (рис. 2). Индивидуальные краниологические данные представлены в табл. 1. Форма черепа в вертикальной норме соответствует сфеноидному варианту. Мозговая коробка характеризуется как брахикранная со средним продольным, очень большим поперечным, большим высотным диаметрами. Высота черепа характеризуется гипсикранией и тапейнокранией. Рельеф нижнего края чешуи лобной кости развит слабо (балл 1). Наибольшая ширина лба - очень большая, наименьшая ширина - средняя. Лицо ортогнатное, невысокое и среднеширокое, орбиты средневысокие и среднеширокие, высота носа очень большая, ширина - большая. Нижний край грушевидного отверстия имеет острую форму. Передненосовой шип оценивается баллом 4. Длина нижней челюсти средняя, наименьшая ширина ветви очень малая, высота - большая. Симфиз невысокий, высота тела очень малая, толщина - средняя.

На черепе выявлены следующие дискретно-варьирующие признаки: отверстия надглазничные (foramina supraorbitalia), лобные (foramina frontalia), скуло-лицевые (foramina zygomaticofacialies), сосцевидные (foramina mastoidea), небные (foramina mentalia), гиперостоз во внутренней области орбит (cribra orbitalia), заднескуловой шов (os zygomaticum bipartitum), выступающая форма латерального края лобного отростка скуловой кости (spina processus frontalis ossis zugomatici), сужение птериона X-образной формы (stenocrotaphia), добавочные косточки неправильной формы в ламбдовидном шве (os wormii suturae lambdoidea), вставная кость в области теменной вырезки (os postsquamosum), прямая форма поперечного небного шва (sutura palatine) и сквозной канал, пронизывающий тело клиновидной кости в области ямки турецкого седла (canalis craniopharyngeus).

Наблюдается прижизненная утрата всех зубов верхней челюсти, кроме правого третьего моляра, атрофия зубных ячеек альвеолярных отростков. На нижней челюсти прижизненно были утеряны резцы, первый и второй моляры, второй премоляр. Мезиодистальный $\left(\mathrm{MD}_{\mathrm{cor}}\right)$ и вестибуло-лингвальный $\left(\mathrm{VL}_{\mathrm{cor}}\right)$ диаметры коронок третьих моляров попадают в категорию малых и очень малых значений (табл. 2). На правом третьем моляре фиксируется необычная стертость зубной ткани. На левом третьем моляре наблюдается эмалевая капля («жемчужина»), она представляет собой избыточное образование ткани зуба в процессе его развития и располагается на корне моляра.

Наблюдается слабое проявление поротического гиперостоза глазниц (cribra orbitalia, балл 1) и в области над наружными слуховыми проходами. Как известно, поротический гиперостоз появляется в ходе компенсаторной реакции организма на снижение в крови количества гемоглобина (малокровие). На левой теменной кости обнаружены две остеомы. Размеры первой $-11 \times 9$ мм, второй $-5 \times 6$ мм. Остеомы - очень плотные образо- 
вания с гладкой поверхностью и по своей структуре ничем не отличаются от нормальной костной ткани.

На левой стороне черепа в области теменной и затылочной костей фиксируется вдавленный заживший перелом от удара тупым орудием. Диаметр костного дефекта $34 \times 18$ мм, край выражен резко. Ближе к ламбде отмечается полукруглая трещина овальной формы, возникшая от удара тупым предметом. Размеры трещины примерно 42 мм. Зафиксировано окостенение гортани. Анатомия гортани представляет собой сложный комплекс мышечных и хрящевых тканей, кровеносных и лимфатических сосудов, нервных окончаний. Как известно, после 30 лет происходит отложение солей кальция, что провоцирует окостенение и потерю подвижности. Окостенение гортани также может быть связано с распространением различных инфекционных заболеваний. Это влечет за собой ухудшение голосовых способностей - речь становится глухой и дребезжащей.

Индивид № 2. Останки принадлежат мужчине, умершему в возрасте 40-49 лет. У индивида наблюдается искусственная лобно-затылочная деформация головы. Форма черепа в вертикальной норме соответствует сфеноидному варианту (рис. 3). Мозговая коробка характеризуется как мезокранная с очень малыми продольным и поперечным диаметрами, средним - высотным (табл. 1). Высота черепа характеризуется гипсикранией и акрокранией. Ширина лба и затылка - средняя. Рельеф нижнего края чешуи лобной кости развит слабо (балл 1), степень выступания надпереносья оценивается баллом 2. Лицо ортогнатное, высокое и среднеширокое, орбиты высокие и широкие, высота и ширина носа очень большая.

На черепе выявлены следующие дискретно-варьирующие признаки: отверстия скуло-лицевые (foramina zygomaticofacialia), сосцевидные (foramina mastoidea), крылоостистые (foramen pterygospinosum), небные (foramina mentalia), непостоянные отверстия позади затылочных мыщелков (canalis condyloideus), выступающая форма латерального края лобного отростка скуловой кости (spina processus frontalis ossis zugomatici), сужение птериона X-образной формы (stenocrotaphia), лобный отросток височной чешуи (processus frontalis squamae temporalis), вставная кость в области теменной вырезки (os postsquamosum), добавочные косточки неправильной формы в ламбдовидном шве (os wormii suturae lambdoidea), в области астериона (os asterion), кость Инков (os Incae incompletum), заднескуловой шов (os zygomaticum bipartitum), П-образная форма поперечного небного шва (sutura palatine), резцовый шов (sutura incisive), сквозной канал, пронизывающий тело клиновидной кости в области ямки турецкого седла (canalis craniopharyngeus), отросток, отходящий от нижней поверхности processus jugularis (processus paramastoideus).

Форма прикуса у индивида лабидодонная. Наблюдается прижизненная утрата моляров ( $\mathrm{M}^{1}, \mathrm{M}^{3}$ /прав./, $\mathrm{M}^{1}, \mathrm{M}^{3}$ /лев./, $\mathrm{M}_{1}, \mathrm{M}_{3}$ /лев./). Мезио-дистальный (MD лингвальный $\left(\mathrm{VL}_{\mathrm{cor}}\right)$ диаметры коронок вторых и третьих моляров попадают в категорию малых и очень малых значений (табл. 2). На правом премоляре фиксируется патологическая стертость зубной ткани, вызванная, очевидно, ненормированной нагрузкой на зубочелюстной аппарат. Гипоконус вторых верхних моляров редуцирован. 4-бугорковые формы отмечены на нижних первых и вторых молярах. На вторых нижних молярах отмечается Y тип узора. Дефект зубной эмали - гипоплазия эмали - фиксируется на правом моляре. Эмалевая гипоплазия свидетельствует о резком стрессовом воздействии, испытанном индивидом в детском возрасте (в интервале от 6 мес. до 7 лет). Следы одонтогенного остеомиелита (альвеолярный абсцесс) наблюдаются на правой стороне верхней челюсти в области второго премоляра и первого моляра, на левой стороне - в районе клыка, первого и второго премоляров, на нижней челюсти в районе вторых резцов. Альвеолярные абсцессы могут быть спровоцированы парадонтитом, травмами и некрозом пульпы. Зубной камень фиксируется почти на всех зубах.

На правой стороне лобной кости обнаружен овальной формы неглубокий, вдавленный перелом (11×7мм). По всей видимости, это заживший след травмы, полученной при 
ударе тупым орудием. На лобной кости виден порез острым предметом (длина 4,5 мм). Наблюдается травма носовых костей.

На теменных костях были обнаружены следы специфических действий. Это множественные длинные, узкие повреждения наружной костной пластинки, нанесенные орудием с острым режущим краем. Подобные манипуляции на черепе - результат символической трепанации. Символическая трепанация является поверхностной (несквозной) манипуляцией, слегка нарушающей целостность свода черепа. Эти шрамы на теменных костях у индивида могли появиться при прохождении какого-то ритуала.

В ушных каналах отмечаются оссеофитные образования. Их появление связывается с напряжением надкостницы и формированием нового костеобразования под действием холодной воды, способствующей сужению кровеносных сосудов в ушном канале.

Индивид № 3. Останки принадлежат молодой женщине, умершей в возрасте 18-22 лет. Форма черепа в вертикальной норме соответствует сфеноидному варианту (рис. 4). На черепе фиксируется искусственная лобно-затылочная деформация. Мозговая коробка характеризуется как брахикранная с очень малым продольным, большим поперечным, очень большими высотными диаметрами черепной коробки. Высота черепа характеризуется гипсикранией и акрокранией. Рельеф нижнего края чешуи лобной кости развит очень слабо. Надбровные дуги представляют собой едва заметные возвышения справа и слева от глабеллы (балл 1). Ширина лба очень большая, ширина затылка - большая. Наружный затылочный выступ развит слабо, в латеральной норме затылок округлый. Лицо ортогнатное, высокое и среднеширокое, орбиты высокие и очень широкие, нос узкий и высокий. Длина нижней челюсти - средняя. Бугристость в области наружной и внутренней поверхностями углов (место прикрепления мышц $m$. masseter и $m$. pterygoideus medialis) нижней челюсти слабо выражена. Тело нижней челюсти очень низкое с большой толщиной.

На черепе выявлены следующие краниоскопические признаки: отверстия скулолицевые (foramina zygomaticofacialia), теменные (foramina parietalia), сосцевидные (foramina mastoidea), небные (foramina mentalia), непостоянные отверстия позади затылочных мыщелков (canalis condyloideus), выступающая форма латерального края лобного отростка скуловой кости (spina processus frontalis ossis zugomatici), лобный отросток височной чешуи (processus frontalis squamae temporalis), височный отросток лобной кости (processus temporalis ossis frontalis), добавочные косточки неправильной формы в ламбдовидном шве (os wormii suturae lambdoidea), в области астериона (os asterion), сужение птериона $\mathrm{X}$-образной формы (stenocrotaphia), П-образная форма поперечного небного шва (sutura palatina), резцовый шов (sutura incisive), двухсоставной затылочный мыщелок (condylus occipitalis bipartitum), отросток, отходящий от нижней поверхности processus jugularis (processus paramastoideus).

Форма альвеолярной дуги - U-образная. В ряду моляров (верхних и нижних) отсутствует последний - третий. Мезиодистальные и вестибулолингвальные размеры первых и вторых нижних моляров попадают в категорию малых значений, а мезио-дистальные и вестибуло-лингвальные размеры первых и вторых верхних моляров входят в категории средних и больших (табл. 2). Рассчитана величина третьего стэп-индекса, который по ширине коронки (VL) составляет 101,86. Гипоконус первых моляров слабо редуцирован (балл 4-), так же, как и метаконус (балл 2), а вторых моляров - полностью редуцирован (балл 3). Лирообразная форма 1-й борозды параконуса (тип 3) наблюдается на первом верхнем моляре. Нижние первые моляры пятибугорковые, вторые четырехбугорковые. На первом нижнем моляре встречается между метаконидом и энтоконидом внутренний средний дополнительный бугорок (ТАМI). Гипоплазия эмали фиксируется на клыках, первом премоляре $\left(\mathrm{P}_{1}\right)$ и втором моляре $\left(\mathrm{M}_{2}\right)$.

Фиксируется поротический гиперостоз в области наружных слуховых проходов, а также оссеофитные образования в ушных каналах. Также зафиксированы несколько 
травматических нарушений. Обнаружено повреждение носовых костей, характерное для удара тупым предметом. На его левой стороне видна трещина. Признаки воспаления в области повреждений не обнаружены. Травма получена от удара слева, т. е. женщина, пытаясь уклониться, отступила чуть назад и влево. Наблюдается нарушение анатомической целостности альвеолы медиального резца. Травма представлена трещиной. В этом случае травма может произойти при необычном по силе воздействии на зуб, например, при грызении (или откусывании) твердой пищи. На левой стороне лобной кости фиксируются последствия рубящего удара (длина 29 мм), нанесенного по касательной, который и являлся причиной смерти индивида.

Индивид № 4. Останки принадлежат мужчине, умершему в возрасте 50-55 лет (рис. 5). На черепе зафиксирована искусственная лобно-затылочная деформация. Мозговая коробка индивида характеризуется как брахикранная, со средним поперечным и очень малым продольным диаметрами. Она средневысокая, по высотно-поперечному указателю - гипсикранная. Величина высотно-продольного указателя характеризуется метриокранией. Лоб узкий, затылок широкий. Лицо прогнатное, высокое и среднеширокое, орбиты высокие и среднеширокие, высота носа - большая, ширина - узкая.

На черепе выявлены следующие дискретно-варьирующие признаки: скуло-лицевые отверстия (foramina zygomaticofacialia), выступающая форма латерального края лобного отростка скуловой кости (spina processus frontalis ossis zugomatici), сужение птериона $\mathrm{X}$-образной формы (stenocrotaphia), лобный отросток височной чешуи (processus frontalis squamae temporalis), височный отросток лобной кости (processus temporalis ossis frontalis), добавочные косточки в области височного родничка (os epiptericum), в чешуйчатом шве (os wormii suturae squamosum), в затылочно-сосцевидном шве (os wormii sut. occipitomastoideum), П-образная форма поперечного небного шва (sutura palatina), резцовый шов (sutura incisive), сквозной канал, пронизывающий тело клиновидной кости в области ямки турецкого седла (canalis craniopharyngeus), отросток, отходящий от нижней поверхности processus jugularis (processus paramastoideus).

Мезио-дистальный $\left(\mathrm{MD}_{\mathrm{cor}}\right)$ и вестибуло-лингвальный $\left(\mathrm{VL}_{\mathrm{cor}}\right)$ диаметры коронок первых и вторых моляров попадают в категорию малых и средних значений (табл. 2). Наблюдается развитие краевых гребней на лингвальной стороне верхних латеральных резцов. Фиксируется пародонтоз $\left(\mathrm{M}^{2}\right)$. Следы одонтогенного остеомиелита (альвеолярный абсиесс) наблюдается на правой стороне верхней челюсти в области $\mathrm{M}^{1}$, на левой стороне $-\mathrm{M}^{2}$. Гипоплазия эмали фиксируется на втором резце $\left(\mathrm{I}^{2}\right)$ и клыке (нижней челюсти). Наблюдается прижизненная утрата моляров ( $\mathrm{M}^{1}, \mathrm{M}^{2}, \mathrm{M}^{3}$ /прав./, $\mathrm{M}_{1}, \mathrm{M}_{2}, \mathrm{M}_{3}$ /лев./, $\mathrm{M}_{3}$ /прав./). Зубной камень фиксируется на исследованных зубах.

На черепе зафиксированы несколько травматических нарушений. 1) Травмы тупыми предметами на правой теменной кости (размеры поражения $14 \times 10,5$ мм и $5 \times 4$ мм). 2) Травма тупым предметом на левой теменной кости (размеры $6 \times 5$ мм). 3 ) Порезы острым орудием надорбитальной области лица.

На черепе выявлены поротический гиперостоз на лобной кости и в области наружных слуховых проходов, а также оссеофитные образования в ушных каналах.

Индивид № 5. Останки принадлежат женщине, возраст которой от 30 до 35 лет. Череп плохой сохранности, отсутствуют лицевой скелет и часть лобной кости (рис. 6). На черепе наблюдается искусственная лобно-затылочная деформация. Поперечный диаметр черепной коробки входит в категорию очень большой, высотный диаметр - малый. Высота черепа характеризуется тапейнокранией. Ширина затылка - большая.

На черепе выявлены следующие дискретно варьирующие признаки: os postsquamosum, foramina parietalia, добавочные косточки неправильной формы в лямбдовидном шве (os wormii suturae lambdoidea), foramina mastoidea, отсутствие foramina spinosum, processus paramastoideus, canalis condyloideus, мендозный шов (sutura mendoza). 
На правом сосцевидном отростке имеется поверхностное нарушение внешней компакты (3×3 мм). Глубина ямки 3 мм. В области травмы наблюдаются элементы склеротизирования краев повреждений. Выявлены на черепе поротический гиперостоз в области наружных слуховых проходов, а также оссеофитные образования в ушных каналах.

Индивид № 6. Степень сохранности черепа плохая, отсутствуют лобная кость, лицевой скелет (рис. 7). Останки принадлежат мужчине, умершему в возрасте 35-39 лет. У мужчины поперечный диаметр черепной коробки средний, а затылок - узкий.

На черепе выявлены следующие дискретно-варьирующие признаки: stenocrotaphia (X-обр.), processus frontalis squamae temporalis, os wormii suturae squamosum, os postsquamosum, foramina parietalia, os wormii suturae lambdoidea, foramina mastoidea, canalis condyloideus.

Из 32 постоянных зубов обнаружен только верхний правый клык, вестибулолингвальный диаметр $\mathrm{VL}_{\text {cor }}$ которого 8,1 мм, мезио-дистальный диаметр шейки $\mathrm{MD}_{\text {col }}-$ 6,5 мм. На клыке выявлены слабая форма гипоплазии эмали и зубной камень.

На черепе выявлены затылочные структуры (развитие затылочных валиков хорошее (TOT: балл 2), позади сосцевидных отростков - маленькое (PR: балл 1). Образование затылочных структур связано с ответной реакцией организма человека на физическую нагрузку, хроническую (многократную) микротравму [Худавердян, 2016, с. 104-105]. Наблюдается также остеоартрит вехнечелюстного сустава. Современная наука рассматривает остеоартрит как заболевание неизвестной этиологии и изучает различные эндогенные и экзогенные факторы риска. К развитию остеоартрита может привести однократная травма, внутрисуставной перелом и воспаления. Поротический гиперостоз отмечается у ушного прохода и на теменных костях. Наблюдаются также экзостозы у ушного прохода.

Индивид № 7. Фрагменты черепа принадлежат ребенку 4-5 лет. На костях черепа выявлены следующие дискретно-варьирующие (неметрические) признаки: os wormii suturae squamosum, foramina parietalia, os Incae (рис. 8), os wormii suturae lambdoidea, os asterion, foramina mastoidea.

Бугорок Карабелли наблюдается на первом верхнем моляре, а редукция гипоконуса отсутствует (M1). Первый нижний моляр пятибугорковый с У типом узора.

Индивид № 8. Фрагменты черепа принадлежат ребенку 2-3 лет. На костях черепа выявлены следующие дискретно-варьирующие признаки: foramina zygomaticofacialia, os wormii suturae squamosum, os wormii suturae lambdoidea, condylus occipitalis bipartitum.

У ребенка пористость и пороз костей наблюдается на костях посткраниального скелета (в частности, области эпифизов плечевых костей). Морфологическая картина характерна для локальных оссифицированных геморрагий (т. е. длившихся некоторое время кровоизлияний). Дифференциальная диагностика данной палеопатологии может включать инфекционное заболевание или витаминную недостаточность. На левой теменной кости обнаружены следы воспаления в виде dura mater на внутренней пластинке (эпидуральная гематома). Вокруг дефекта отмечается деструкция кортикального слоя. Эндокраниальные патологии, зафиксированные на костных останках ребенка, являются результатом воспаления или кровоизлияния мозговых оболочек черепа и связаны с широким спектром заболеваний (опухоли, туберкулез, менингит, сифилис, вторичная инфекция мозговой оболочки, недостаток витаминов A, С и D и т. д.) [Hershkovitz, Greenwald, Latimer, Jellema, WishBaratz, Eshed, Dutour, Rothschild, 2002, p. 201-216; Lewis, 2004, p. 82-97].

Индивид № 9. Фрагменты черепа принадлежат ребенку 1,4-1,6 лет. На костях присутствует только foramina mastoidea (дискретно-варьирующий признак). Воспаление правого сосцевидного отростка височной кости (мастоидит) наблюдается на черепе.

Итак, у исследованных индивидов (№№ 1, 2, 3, 4, 5) обнаружены искусственная деформация головы (рис. 9, 10). Изменение величины и формы свода черепа свидетельствует о врожденных или приобретенных деформациях. Приобретенные деформации могут быть естественными, т. е. последствиями болезни (плагиоцефалия, рахит, акромегалия 
и т. д.), и искусственно вызванными. Гиппократ описывал обычай искусственной деформации головы у народов, обитавших по берегам Черного и Азовского морей. В зависимости от способов преднамеренной деформации и распространения деформирующих воздействий на кости черепа, Е.В. Жировым [Жиров, 1940, с. 81-88] была предложена следующая классификация видов деформации: кольцевая, подразделяющаяся, в свою очередь, на высокую (с лобно-затылочным уровнем деформирующих воздействий) и низкую (при которой давящая повязка располагается на теменных костях или на теменнозатылочной области и нижней челюсти), лобно-затылочная, теменная и затылочная. Однако встречается множество переходных видов деформаций. В Ованнаванке наблюдается деформация 2-х типов: кольцевая лобно-затылочная башанного типа и кольцевая лобнозатылочная, приближающаяся по форме к конусу. При первом типе лобная кость выпрямлена и вытянута вверх, затылочная кость уплощена и не имеет соответствующего ей изгиба и также вытянута вверх (индивиды $1,2,4,5$, рис. 9). От давления циркулярной повязки на лобных костях выявлены следы широкой уплощенной полоски, на затылочной кости неглубокий желоб. При втором типе лобная кость наклонена назад и вытянута вверх, затылочная кость уплощена и вытянута вверх, а теменные кости выпуклы в области сагиттального шва (индивид 3 , рис. 10). Средства и методы, используемые для получения необходимой формы, степени выражения деформации на черепе, были самыми разнообразными. Использовались повязки, бинты, косынки, деревянные, костные, каменные накладки. У некоторых этнических групп, начиная с первых дней жизни новорожденного, производилась «формовка» головы ребенка руками [Дьяченко, 1988, с. 46-49].

Мотивы преднамеренной деформации головы могут быть следующие - традиции или медицинские процедуры: 1) непреднамеренное воздействие предмета быта (особый вид колыбели, приводящий к уплощению затылочной кости); 2) подчеркивание социального статуса и отличие от инородных групп; 3) исправление «неправильной» формы черепа и получение «красивой» формы головы, удовлетворяющей определенным эстетическим нормам; 4) возможность изменить психотип человека; 5) необходимость приостановить быстрый рост мозгового вещества; 6) стремление ускорить процесс зарастания родничка; 7) результат массажа (для снятия головных болей); 8) желание защитить голову новорожденного от природных факторов (холод, ветер, жара) [Попов, Чикашева, Шпакова, 1997, с. 58; Худавердян, 2005, с. 91-95; Khudaverdyan, 2011a, p. 602-609; 2011b, p. 39-41].

Характер и локализация травм на скелете указывают на определенную общественную обстановку, в которой могли складываться те или иные травмоопасные ситуации. Поэтому антропологические материалы являются независимым источником в археологических реконструкциях, выполняемых в ходе комплексных археологических исследований. Травмы с признаками заживления костной ткани встречаются у 4-х индивидов. Травма с летальным исходом обнаружена у одного индивида (N 3, ㅇ 18-22 лет). К разряду лицевых травм можно отнести: заживший перелом носовых костей (N 3, q 18-22 лет; $\mathrm{N} 2$, ○ 40-49 лет), повреждение верхней челюсти ( $\mathrm{N} 3$, q 18-22 лет) и надорбитальной области (N 4, ○ 50-55 лет; N 2, § 40-49 лет). Травмы носовых костей получены от удара слева, т. е. индивиды пытались уклониться, отступили чуть назад и вправо. Повреждение нижней челюсти - это последствие удара по лицу в область передних зубов или при грызении (или откусывании) твердой пищи. А травмы в надорбитальной области получены от контактного удара с правой стороны, т. е. мужчины не успели отреагировать на удар. К другому варианту можно отнести вдавленное повреждение от удара тупым предметом в левую сторону лобной кости (N 2, § 40-49 лет). Следы заживления и отсутствие признаков воспалительного процесса свидетельствуют о том, что травмы были получены задолго до смерти индивидов. В другом случае - продолговатый шрам (N 3, o 18-22 лет: длина рубца 29 мм; N 2, శ 40-49 лет: длина рубца 4,5мм) от орудия с острым режущим краем обнаружен на лобной кости слева. У двух индивидов наблюдаются трещины от ударов тупым предметом (N 1, 45-55 лет, N 3, 18-22 лет). Два других варианта повреждений 
отличаются от предыдущих локализаций: они выявлены на теменных костях и на сосцевидном отростке. У мужчины (N 4, 50-55 лет) и у двух женщин отмечены следы заживших переломов теменных костей (N 1, 45-55 лет, N 5, 30-35 лет). На указанных черепах фиксируются вдавления верхней пластинки теменной кости с правой стороны, на двух из них (N 4, 今 50-55 лет; N 5, क 30-35 лет) также обнаружены дефекты с левой стороны. У женщины (N 5, 9 30-35 лет) на правом сосцевидном отростке имеется поверхностное нарушение внешней компакты $(3 \times 3$ мм). Глубина ямки 3 мм. В области травмы наблюдаются элементы склеротизирования краев повреждений.

В изучаемой группе выявлены высокие показатели встречаемости такой патологии, как поротический гиперостоз. У одного взрослого индивида (N 1, q 45-55 лет) был зафиксирован поротический гиперостоз глазниц (cribra orbitalia). По данным некоторых палеопатологов, cribra orbitalia в большинстве случаев ассоциируется с железодефицитной анемией, которая развивается при хроническом течении инфекционных и паразитарных заболеваний [Ortner, Putschar, 1981; Larsen, 1997]. Поротический гиперостоз костей свода черепа был зафиксирован на 6 черепах (N 2, § 40-49 лет; N 3, ठ 18-22 лет; N 4, § 50-55 лет; N 5, 9 30-35 лет; N 6, § 35-39 лет; N 8, ребенок 2-3 лет). Некоторые исследователи пологают, что эти патологические проявления на костных останках взаимосвязаны [Ortner, Putschar, 1981; Larsen, 1997].

У индивидов обнаружены доброкачественные образования. У одного индивида на левой теменной кости (N 1, q 45-55 лет) выявлены две остеомы. Остеома - доброкачественная опухоль, может возникнуть после тяжелой травмы, инфекционного поражения

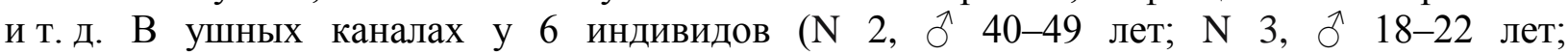
N 4, ठ 50-55 лет; N 5, о 30-35 лет; N 6, § 35-36 лет; N 8, ребенок 2-3 лет) отмечаются оссеофитные образования. Их появление связывается с напряжением надкостницы и формированием нового костеобразования под действием холодной воды, способствующей сужению кровеносных сосудов в ушном канале.

Экспертизой выявлено у ребенка (N 9, 1,4-1,6 лет) воспаление правого сосцевидного отростка височной кости (мастоидит). Воспаление ячеек сосцевидного отростка чаще является осложнением острого гнойного воспаления среднего уха. При мастоидите бактерии проникают из среднего уха в ячейки сосцевидного отростка, где воспаление приводит к разрушению костных структур [Nussinovitch, Yoeli, Elishkevitz, Varsano, 2004, p. 261-265].

Следы локальных кровоизлияний (оссифицированных геморрагий) обнаружены на поверхности посткраниального скелета у ребенка $(\mathrm{N} 8,2-3$ лет) и могут указывать на недостаток в пище витамина С (т. е., на детскую цингу). У данного ребенка выявлено воспаление в виде dura mater на внутренней пластинке черепа, что, вероятно, имеет геморрагическое свойство. Следов прижизненных травматических повреждений следствием, которой мог возникнуть геморрагический процесс на внутренней поверхности кости свода черепа, у индивида не обнаружено, что исключает возможность возникновения воспаления из-за травмы. Вероятными причинами данной патологии могут быть цинга, бактериальные или вирусные менингиты и т. д.

Эмалевая гипоплазия свидетельствует о резком стрессовом воздействии, испытанном индивидом в детском возрасте (в интервале от 6 мес. до 7 лет). Дефект зубной эмали

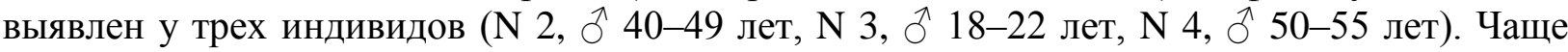
признак зафиксирован на клыках, премолярах и резцах. У двух индивидов ( $\mathrm{N} \mathrm{1,}$, 45-55 лет, $\mathrm{N} 4$, О 50-55 лет) фиксируется пародонтоз. Причинами возникновения данного заболевания могут быть разнообразные факторы: инфекционные заболевания, нарушение питания, обмена веществ, расстройства эндокринной системы, возрастной фактор, нарушение витаминного баланса, плохая оральная гигиена, богатая углеводами пища, различные аномалии роста зубов, осложнения, возникающие во время беременности [Hillson, 1986; Larsen, 1997]. Пародонтоз обнаружен в области моляров 
( $\mathrm{M}^{2}: \mathrm{N} 4$, ठ 50-55 лет; $\mathrm{M}_{1}$ и $\mathrm{M}_{2}: \mathrm{N} 1$, $~ 45-55$ лет). Зубной камень зафиксирован у 3 инди-

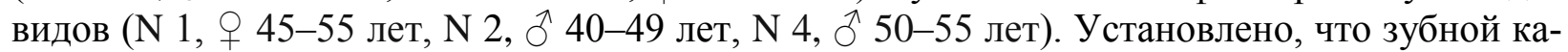
мень и пародонтоз - сопутствующие друг другу патологии зубной системы [Hillson, 1986]. Следы одонтогенного остеомиелита (альвеолярный абсиесс) обнаружены у двух индивидов (N 2, ภ 40-49 лет, N 4, § 50-55 лет). Альвеолярный абсцесс наблюдается у мужчины 50-55 лет $(\mathrm{N} 4)$ на правой стороне верхней челюсти в области первого моляра $\left(\mathrm{M}^{1}\right)$ и на левой стороне в области второго моляра $\left(\mathrm{M}^{2}\right)$. У второго индивида (N 2, ठ 40-49 лет) признак зафиксирован как на верхней челюсти (на правой стороне в области второго премоляра $\left(\mathrm{P}^{2}\right)$ и первого моляра $\left(\mathrm{M}^{1}\right)$, на левой стороне в области клыка $(\mathrm{C})$, первого и второго премоляров $\left(\mathrm{P}^{1}, \mathrm{P}^{2}\right)$, так и на нижней челюсти в области латерального резца $\left(\mathrm{I}_{2}\right.$ : с двух сторон). Альвеолярные абсцессы могут быть спровоцированы парадонтитом, травмами и некрозом пульпы. Фиксируется у мужчины 40-49 лет (N 2) патологическая стертость зубной ткани $\left(\mathrm{P}^{2} /\right.$ прав/), вызванная, очевидно, ненормированной нагрузкой на зубочелюстной аппарат или же аномалией прикуса. Преждевременное стирание эмали и дентина могло быть обусловлено и диетой с использованием жесткой и грубоволокнистой пищи. Прижизненная утрата зубов наблюдается у 3 индивидов (N 1, о 45-55 лет, N 2, ô 40-49 лет, $\mathrm{N} 4, \widehat{\jmath}$ 50-55 лет). Наиболее часто были утеряны моляры.

В дальнейшем представим обобщенную антропологическую (краниометрическую, краниоскопическую, одонтологическую) характеристику индивидов из Ованнаванка. Мужские черепа имеют брахикранную черепную коробку с очень малым продольным, малым поперечным, средним высотным диаметрами. Высота черепа характеризуется гипсикранией и акрокранией. Лицо мезогнатное, среднеширокое, высокое, уплощенность горизонтального профиля средняя. Орбиты среднеширокие и высокие. Нос высокий и широкий, небо узкое, среднеширокое. Останки женщин характеризуются общей грацильностью строения, с очень слабо выраженным рельефом в области надбровья. Черепная коробка брахикранная, с малым продольным, большим поперечным, большим высотным диаметрами. Высота черепа характеризуется гипсикранией и метриокранией. Наибольшая ширина лба - очень большая, наименьшая ширина большая. Лицо ортогнатное, средневысокое и среднеширокое, орбиты высокие и широкие, высота носа - большая, ширина - средняя. Сравнение дисперсий обнаруживает существенное повышение изменчивости 32 признаков и указателей [Алексеев, Дебец, 1964]. Достоверное преобладание эмпирических дисперсий фиксируются только 8 признаков и указателей: 46, 60, 62, 9:45, 77, <zm, 52:51, 52:51a [Худавердян, Жамкочян, Акопян, 2016, с. 13-21].

У индивидов Ованнаванка завышенные частоты следующих краниоскопических (дискретно-варьирующих) признаков: горизонтального шва скуловой кости, умноженного подбородочного отверстия, птериона Х-образной формы, выступающей формы латерального края лобного отростка скуловой кости, шовных косточек в ламбдовидном, чешуйчатом швах, резцового шва, проникающего тела клиновидной кости в области ямки турецкого седла, отростка затылочной кости (processus paramastoideus), непостоянных отверстий позади затылочных мыщелков (canalis condyloideus), вставной кости в области теменной вырезки, лобного отверстия и отростка височной чешуи, височного отростка лобной кости, отверстий в затылочно-сосцевидном шве, теменных, добавочных косточек неправильной формы в области астериона, двусоставного затылочного мыщелка. Наблюдаются умеренные и низкие частоты встречаемости надглазничных, подглазничных, крылоостистых отверстий, Инковских и межвисочных костей, мендозного шва, отсутствия задней стенки остистого отверстия (foramen spinosum inco.). У погребенных отсутствуют следующие дискретно варьирующие признаки: sutura frontalis, spina trochlearis, os parietale bipartitum, os wormii suturae coronalis, os bregmaticum, os wormii suturae sagittalis, os triquetrum, os quadratum, os apicis lambda, os interparietale s. sagittalis, propcessus interparietalis, 
manifestatio vertebrae occipitalis, tuberculum praecondylare, sulcus mylohyoideus, foramina mandibularia.

Одонтологический комплекс характеризует индивидов как представителей «западного» одонтологического ствола. Полученные результаты свидетельствуют о преобладании у населения псалидодонтной формы прикуса. У одного индивида встречается лабидодонтная форма. Диастемы между верхними медиальными резцами не выявлены. Общая частота встречаемости краудинга в группе 33,34 \% (1/3). На латеральных резцах лопатообразной формы зафиксированы у одного индивидуума. Редукция гипоконуса на вторых верхних молярах выявлена у $66.67 \%$ субъектов (2/3). Встречаемость бугорка Карабелли равна 33,34 \% (1/3). Форма 3 первой борозды эоконуса на первом верхнем моляре выявлена у одного индивида. Отсутствуют шестибугорковые формы на первых нижних молярах, пятибугорковые формы характеризуются высокими частотами распространенности $(75 \%, 3 / 4)$, четырехбугорковые формы отмечены у одного индивидуума. Межбугорковые борозды на первом нижнем моляре фиксируют высокую частоту «у» тип узора. Четырехбугорковые формы вторых нижних моляров выявлены у 2 субъектов $(66,67 \%, 2 / 3)$. Межбугорковые борозды на втором нижнем моляре фиксируют «Х» тип узора. На нижней челюсти практически полностью отсутствуют признаки восточного одонтологического ствола. Протостилид, дистальный гребень тригонида, 6-бугорковые первые нижние моляры, коленчатая складка метаконида не встречены. Внутренний средний дополнительный бугорок на первом нижнем моляре зафиксирован у одного индивидуума. Вариант «2» второй борозды метаконида также встречается у одного субъекта.

Краниологические данные были подвергнуты межгрупповому статистическому анализу. Сравнительный фон, выбранный для анализа, охватывает территории Кавказа, Ближнего Востока и Юго-Восточной Европы ${ }^{23}$ (табл. 3).

На первом этапе межгруппового анализа была построена модель на основе данных о 14 размерах черепа и лица (табл. 4) в 75 группах с Кавказа и из Юго-Восточной Европы. На рис. 11 показано положение рассматриваемых групп в пространстве I и II канонических векторов (КВ). Первый КВ (29.97 \% общей изменчивости) разделил анализируемые группы по комплексу признаков, из которых основными являются соотношение продольного и поперечного диаметров черепа и ширина лба. По КВ I серии из КабардиноБалкарии (43, 42), Северной Осетии (44), Дагестана $(31,28)$, Грузии $(13)$, Азербайджана $(17,18)$, Волго-Уралья $(61-66,74,70,72)$, Украины (92) демонстрируют максимальные значения и сконцентрированы в положительном поле изменчивости в правой части графика. Почти все они характеризуются мезо- и брахикранией, широким и высоким лицом. В отрицательном поле изменчивости локализованы серии из Дагестана $(30,29)$, Азербайджана (14-16), Армении (2, 6), с Северо-Западного Кавказа (60), из Северной Осетии (47), Дунайско-Днестровского региона (94), Западной Украины (93), Краснодарского края (33, $35,38)$, Волго-Уралья $(68,85,83)$ и Карачаево-Черкесии $(41,39)$.

В КВ II (23 \% изменчивости) наибольшая нагрузка пришлась на высоту орбиты. Положение анализируемых групп в пространстве второго вектора-дискриминатора показывает высокие положительные величины у групп из Средней Волги $(84,65,90,76,73)$, Дагестана (31), Грузии $(9,10,12,13)$, Азербайджана $(17,18)$ и Армении (4).

Ованнаванкская серия (4) обнаруживает сходство с кавкасионскими группами из Грузии $(10,13,12,9)$. К ним примыкают индивиды из христианских и мусульманских погребений могильника Мингечаур. Следовательно, краниологическую серию из Ованнаванка (4) отличает внутригрупповая неоднородность. Различия в морфологической характеристике черепов довольно четко прослеживаются визуально для мужской выборки и

23 Данные о сериях взяты из сводки А.Ю. Худавердян [см. Худавердян, Жамкочян, Акопян, Бабаян, Енгибарян, Хачатрян, Еганян, 2018, с. 78-84]. 
для женской. Как было указано выше, для ряда признаков были выявлены повышенные значения стандартных отклонений. В число последних входят ширина лица $(46,45)$, длина неба и альвеолярной дуги, углы горизонтальной профилировки лицевого скелета, а также орбитные и лобно-скуловой указатели. К тому же у пяти индивидов фиксируется горизонтальный шов скуловой кости (os zygomaticum bipartitum), у двоих - кость Инков (os Incae), у одного - форма 3 первой борозды эоконуса на первом верхнем моляре. На типологическое сходство хевсурской, душетской серий с мингечаурскими группами еще в 1964 г. указывал М.Г. Абдушелишвили [1964, с. 22]. В одном кластере вместе с ованнаванкской (4) и кавкасионскими группами Грузии $(10,13,12,9)$ оказалась серия с кладбища у здания Греческой палаты (73). Известен факт, что данный некрополь принадлежал жителям христианской армянской колонии в г. Булгаре, и мужские черепа этой серии, гипербрахикранного европеоидного типа, по мнению Т.А. Трофимовой [Трофимова, 1956, с. 85-88], почти по всем признакам сопоставимы с серией современных армянских черепов.

Сравнение 51 женской серии проводилось по 14 основным признакам (табл. 5). В результате в первом КВ (отражает 43,854 \% общей изменчивости) наибольшие нагрузки пришлись на высотные размеры лица $(52,55,48)$. В пространстве КВ I высокими положительными величинами характеризуются группы Южного Кавказа $(4,7,18,9,19)$, Северной Осетии (48) и Волго-Уралья $(74,87,90,66)$, а отрицательными - группы Чигирина (92), Маджар (59), Гамовского и ближайших ущелий (32). Кавкасионский морфологический комплекс, присутствующий в составе серий из Грузии (8-10), сближается с группой из Памятного знака (87) (рис. 19). В числе близких к указанным сериям находится выборка из погребений мусульманского типа Самухского района Азербайджана (18). Черепа в основном брахикранные в комплексе с высоким, слабо профилированным лицевым скелетом и высокими глазницами. Из общей картины «выбивается» гипербрахикранная серия из Ованнаванка (4). Данная краниологическая серия наиболее сильно отличается от остальных материалов с территории Южного Кавказа, демонстрируя иной комплекс краниологических особенностей.

Для КВ II (21,46 \% общей изменчивости) определяющими стали поперечный, продольный диаметры, угол выступания носовых костей. На плоскости II векторадискриминатора высокие отрицательные значения обнаружены у черепов из могильников с территорий Астраханской области $(66,64)$, Среднего $(86,90,74,78)$, Нижнего Поволжья и Нижнего Подонья (63), Молдовы (95), Карачаево-Черкесии (43), Северной Осетии (55) и Армении (4). На противоположном положительном полюсе сгруппировались серии Северной Осетии (47-49), Грузии (7), Азербайджана $(16,14)$, Армении $(2,6)$, КарачаевоЧеркесии (40), Северо-Западного Кавказа (60) и Средней Волги (79). Выборка из Двина (1) оказывается статистически наиболее близка к сборной серии черняховской культуры из Дунайско-Днестровского региона (94). Но последняя несколько отклоняется в сторону группы Маячного II (65) золотоординского периода. Мезокранные, ортогнатные, сильно профилированные черепа с низкими орбитами, среднешироким носом характерны для населения Астраханской области. Примечательно, что и женская серия из Мощевой Балки (60) сближается с более ранней группой (6) из Армении. Сходный комплекс признаков наблюдается среди населения катакомбных погребений Мингечаура (14). Черепа здесь в основном долихокранные, средневысокие, лица среднеширокие, сильно профилированные, глазницы средневысокие.

На широком сравнительном фоне особенно отчетливо видно (рис. 12), что наибольшее сходство наблюдается между синхронными выборками из могильников Гарни (5), Верхний Чир-Юрт (27) и ранней группой из Карачаево-Черкесии (39). В свою очередь, в этом кластере оказалась мезобрахикранная со среднешироким или широким лицом группа из поселения Жукова (33), которая представляет одну и ту же комбинацию антропологических признаков, присущих индивидам поздней группы из Карачаево-Черкесии (40). 
Для того чтобы учесть древние ближневосточные серии, был дополнительно проведен анализ с уменьшенным набором из 10 признаков (табл. 6). В результате первые два наиболее информативных КВ отразили в совокупности 57,654 \% изменчивости. Наиболее значимыми признаками по КВ I (46,8 \% общей изменчивости) для межгрупповой дифференциации 63 серий являются длина и ширина черепной коробки. На разных полюсах межгрупповой изменчивости признаков, которую описывает первый дискриминатор, оказались: с одной стороны - группы из Дагестана $(31,28)$, Северной Осетии $(44,55)$, Кабардино-Балкарии $(43,42)$, Ставропольского края $(59)$, Ирана $(25,24)$, Грузии (8-13), Азербайджана (17-18), Молдовы (95) и Армении (4), с другой - краниологические материалы с территорий Израиля (26), Месопотамии (19), Турции (23), Краснодарского края (38), Черкесии (41), Северной Осетии (47-49), Азербайджана (14-16), Армении $(6,2)$, Северо-Западного Кавказа (60), Дунайско-Днестровского региона (94) и Западной Украины (93).

Добавление в анализ новых серий несущественно изменило взаимное расположение уже использованных в первом анализе мужских выборок с территории Армении (рис. 13). Однако, помимо серий кавкасионского типа из Грузии $(11,8)$ и черепов из погребений христианского типа из Мингечаура (17), в списке наиболее близких к выборке из Ованнаванка (4) оказывается группа Туранг Тепе (25) с территории Ирана. В свою очередь, результаты проведенного анализа свидетельствуют об антропологическом сходстве вышеуказанных групп с североосетинскими брахикранными матуризованными черепами из погребений из каменных ящиков Харха в Дарьяльском ущелье (55). Расположение серий свидетельствует о наибольшей близости выборки из Мощевой Балки (60) к сериям из Армении (6) и Месопотамии (19). В числе близких к указанным сериям находится также выборка из Карачаево-Черкесии (41). Наиболее массивными являются черепа в средневековой серии с территории Турции - Богазкой (23), которые особенно своеобразны и не похожи на другие серии.

В КВ II (10,854 \% изменчивости) наибольшие нагрузки пришлись на ширину орбиты и высоту носа. Положение анализируемых групп в пространстве второго векторадискриминатора показывает высокие положительные величины у групп с Южного Кавказа $(2,7,14-16)$ и Месопотамии (22). На плоскости II вектора-дискриминатора высокие отрицательные значения обнаружены у черепов из могильников с территорий Турции (23), Ирана (24) и Армении (1). Как показал сравнительный анализ, близкое сходство морфологических характеристик серия из Армавира (2) демонстрирует с выборками из катакомбных погребений Азербайджана $(14,15,16)$. Здесь наиболее удалены искусственнодеформированные черепа из могильника Мингечаур (16), у которых продольные и поперечные размеры черепной коробки чуть меньше, а высотные диаметры $(17,48,52)-$ больше.

Итак, данное исследование достаточно отчетливо указывает на неоднородность населения Армении в эпоху средневековья. Намечаются отдельные сочетания краниологических признаков южно-европеоидной расы, которые встречаются в различных комбинациях. Среди жителей Ованнаванка в период позднего средневековья наличествуют специфические комплексы признаков, не характерные, судя по имеющимся сегодня краниологическим данным, для армянского населения более ранних эпох. Этот комплекс признаков близок к кавкасионскому типу. Ближайшие аналоги к этому комплексу обнаружены в составе населения Грузии, Азербайджана (Мингечаур) и Ирана (Туранг Тепе).

Несколько слов о происхождении кавкасионского типа. Он получил свое название от грузинского названия Кавказа - Кавкасиони и был выделен в качестве самостоятельного в 1953 г. [Натишвили, Абдушелишвили, 1955, с. 62-68]. Исходя из специфических краниологических признаков кавкасионского типа - чрезвычайно большой ширины лицевого скелета и некоторой его уплощенности в верхней части, четко выра- 
женной брахикрании, Г.Ф. Дебец [Дебец, 1956] высказал предположение о генетических связях их с населением евразийских степей эпохи бронзы. Брахикранию же кавкасионских групп исследователь был склонен считать местным и поздним явлением. Древние восточноевропейские аналогии Г.Ф. Дебеца [Дебец, 1956] были восприняты некоторыми исследователями как предположение о возможности проникновения предков кавкасионцев в область их современного расселения с севера. Именно так можно рассматривать работу Н.Н. Миклашевской [Миклашевская, 1959, с. 89-110], которая привлекает к аргументации этой идеи материалы о древнем населении Дагестана сарматского и хазаро-аланского периода. Идеи Г.Ф. Дебеца [1956] развивает и А.В. Шевченко [1986, с. 121-215]. Анализируя краниологические группы северокавказской и древнеямной культур, принадлежащие, по его мнению, к «обширной, слабо дифференцированной антропологической формации, занимавшей степи Восточной Европы в эпоху неолита - ранней бронзы» [Шевченко, 1986, с. 128], и сопоставляя их с близкими к современности сериями черепов кавкасионского типа, исследователь разделяет мнение Г.Ф. Дебеца о северном степном происхождении кавкасионской расы. В.П. Алексеев [Алексеев, 1974, с. 134-138] разделял гипотезу изоляции как главного формообразующего фактора, категорически выступал против идеи участия в формировании кавкасионцев элементов северного происхождения [Миклашевская, 1959, с. 89-110]. В.П. Алексеев [Алексеев, 1974, с. 134-138] считает, что изоляция сохранила морфологические особенности древнейшего населения, впервые заселившего высокогорные массивы Кавказа еще в эпоху палеолита. А.В. Шевченко [Шевченко, 1986, с. 198-202] не согласен с В.П. Алексеевым [Алексеев, 1974, с. 100] в том, что «брахикрания современных представителей кавкасионского типа представляет собой позднее образование», и показал, что предкавказские степи Северо-Западного Прикаспия и Калмыкии в конце III - начале II тыс. до н. э. были зоной сплошной брахикрании. Между тем не только предкавказские степи Северо-Западного Прикаспия и Калмыкии были зоной брахикрании, брахикранные варианты в указанный период фиксируются на палеоантропологических материалах Передней Азии и Армянского нагорья [Худавердян, Гаспарян, Пинхаси, Канаян, Ованесян, 2017, с. 85-86]. С идеей формирования кавкасионского типа, как результата «консервации» солидарна также Э.Н. Джавахишвили [1966, c. 106-107].

Автохтонность кавкасионского типа находит обоснование в работах М.Г. Абдушелишвили [Абдушелишвили, 1964, 1972, с. 119-129] и А.Г. Гаджиева [Гаджиев, 1975]. Согласно М.Г. Абдушелишвили, процесс брахикефализации и увеличение скулового диаметра начались с эпохи бронзы и привели в конечном итоге путем постепенной перестройки узколицых грацильных вариантов к современному кавкасионскому типу. Интенсивность развития этого процесса, по мнению исследователя, была зафиксирована в средние века. К этому же выводу пришел А.Г. Гаджиев, изучая палеоантропологию Дагестана.

Результаты представленных исследований склоняют «чашу весов» в пользу концепции автохтонного развития кавкасионского типа. А что говорят данные археологии о происхождении кавкасионского типа? Несомненно, они свидетельствуют в пользу указанной концепции. По мнению А.Г. Козинцева [Козинцев, 1974, с. 198-214], носители этого типа являются потомками древних аборигенов, обитателей горных районов - это племена культуры грубой керамики. В эпоху, предшествовавшую III тыс. до н. э., эти люди заселяли, очевидно, по крайней мере, весь Северный Кавказ. Пришельцы с Южного Кавказа, заняв западную и восточную части ареала протокавкасионцев, взяли последних в «клещи». Эти «клещи» сжимались до тех пор, пока потомки местного населения не были оттеснены в горные районы (вероятно, недоступные пришельцам), где, консолидировавшись, и образовали кавкасионский тип с его компактным ареалом [Козинцев, 1974].

О присутствии индивидов - представителей кавкасионского типа в Ованнаванке сообщается в источниках (Закарий Канакерци [1969, с. 269-271]): «...Когда погиб мучени- 
ческой смертью святой Георгий в Кападокии, тело его хранили ... в Ованнаванке... В это время напала на сына царя грузинского злая болезнь-короста, и не нашел он [себе] исцеления. Тогда рассказали царю: «Есть ... один монастырь, который зовется Ованнаванк, и там находится тело святого Георгия, и собираются там все прокаженные и калеки и находят себе исцеление у святого Георгия. Так пошли туда сына твоего, и исцелится он» .... И вот надумал он [царь] отправить [людей], чтобы привезти кости святого Георгия... Тогда собрал царь много детей дворянских и отправил их заложниками... их было двенадцать, которые прибыли к вратам Ованнаванка. Они же (монахи) задержали у себя детей, а из мощей святого оставили там часть зубов и кровь, все же тело приготовили к отправке. И так остался он (святой Георгий) в стране Грузинской, а дети грузинские остались в стране Армянской и по сие время».

Историография повествует [Канакерци, 1969, с. 273], что «Дети грузин остались в Ованнаванке... один умер в Ованнаванке... Один, по имени Теин, остался в Ованнаванке, и ныне зовутся [его потомки] Теиненк; другой, по имени Азипе, ушел в Егвард, и ныне [их] зовут Азипенк; следующий, по имени Муца ушел в Канакер, и вот зовут их Моцакенк; следующий, по имени Хачо, ушел в Могни, и вот зовут [их] Хачикенк; один [из них], по имени Степанос, ушел в Бюракан и родил сына по имени Бабаджан, и вот зовут их Бабаджаненк; следующий по имени Шалове ушел в Газараван и родил сына по имени Баба, и зовут [их] Бабенк; а некий. по имени Гапо, взяв сестру свою по имени Агута, ушел в Канакер, и зовутся они Гапонк».
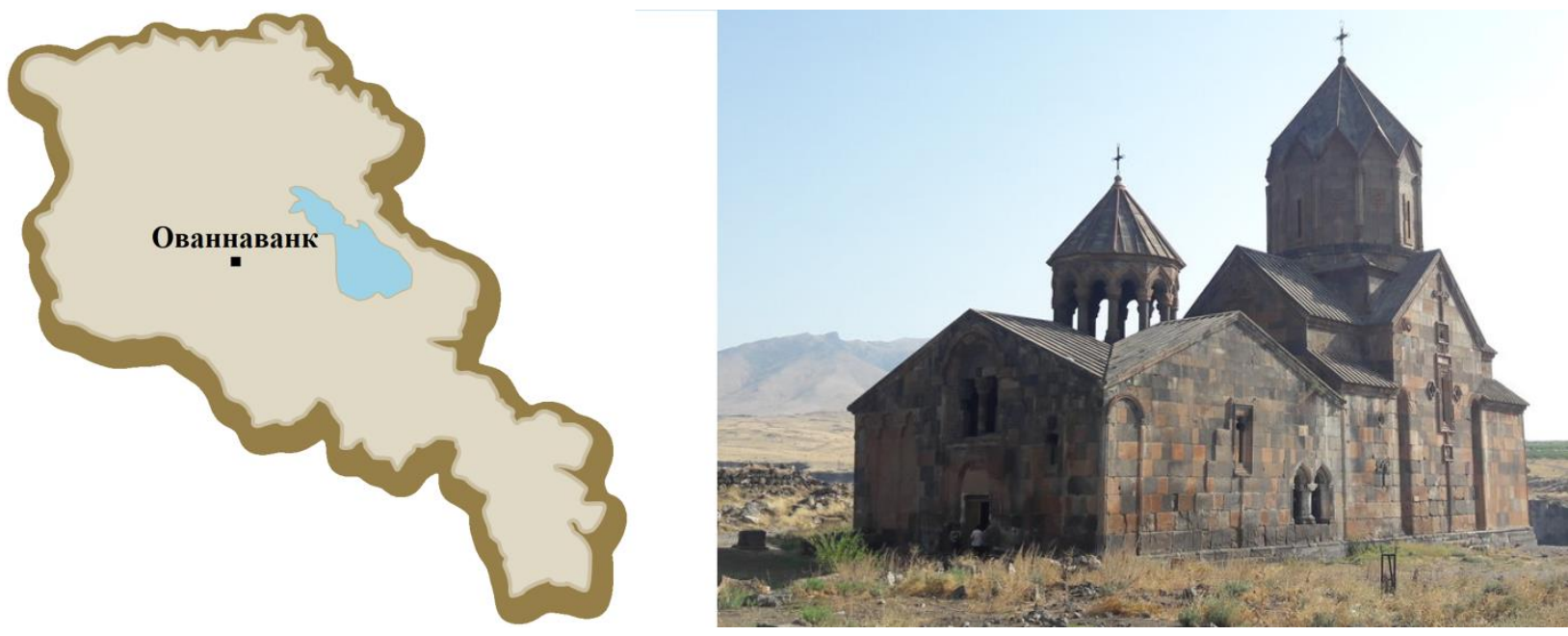

Рис. 1. Расположение на карте Армении монастырского комплекса Ованнаванк

Fig. 1. Location on the map of Armenia of the Hovhannavank monastery complex
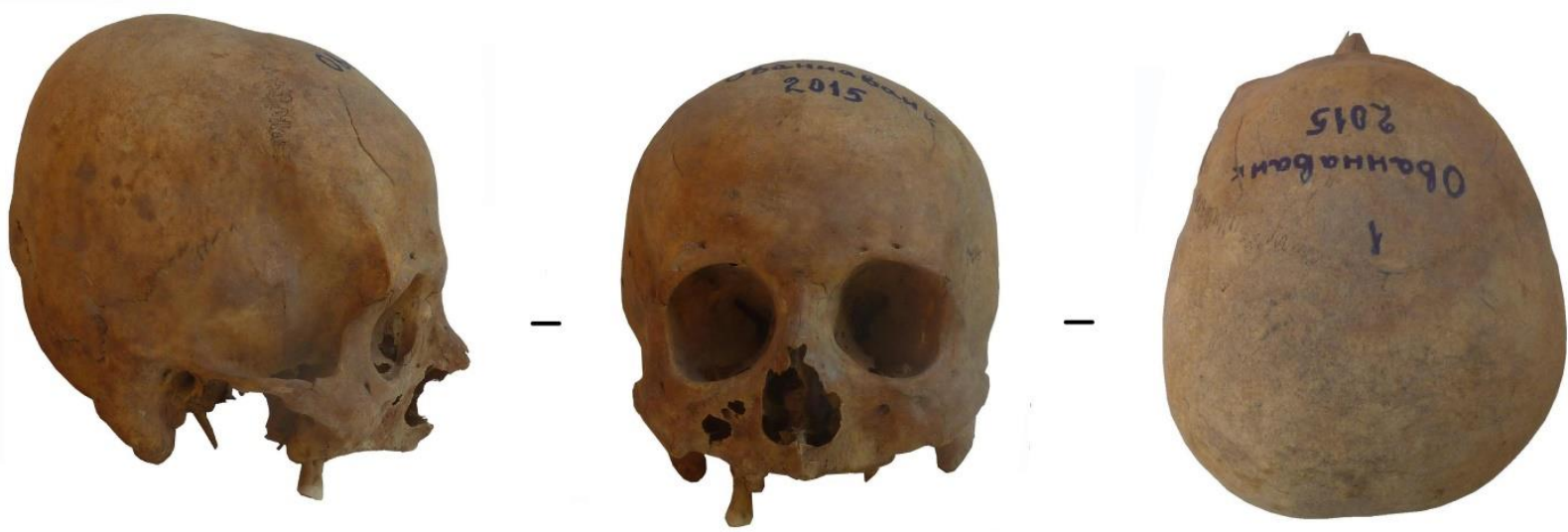

Рис. 2. Индивид № 1

Fig. 2. Individual No. 1 

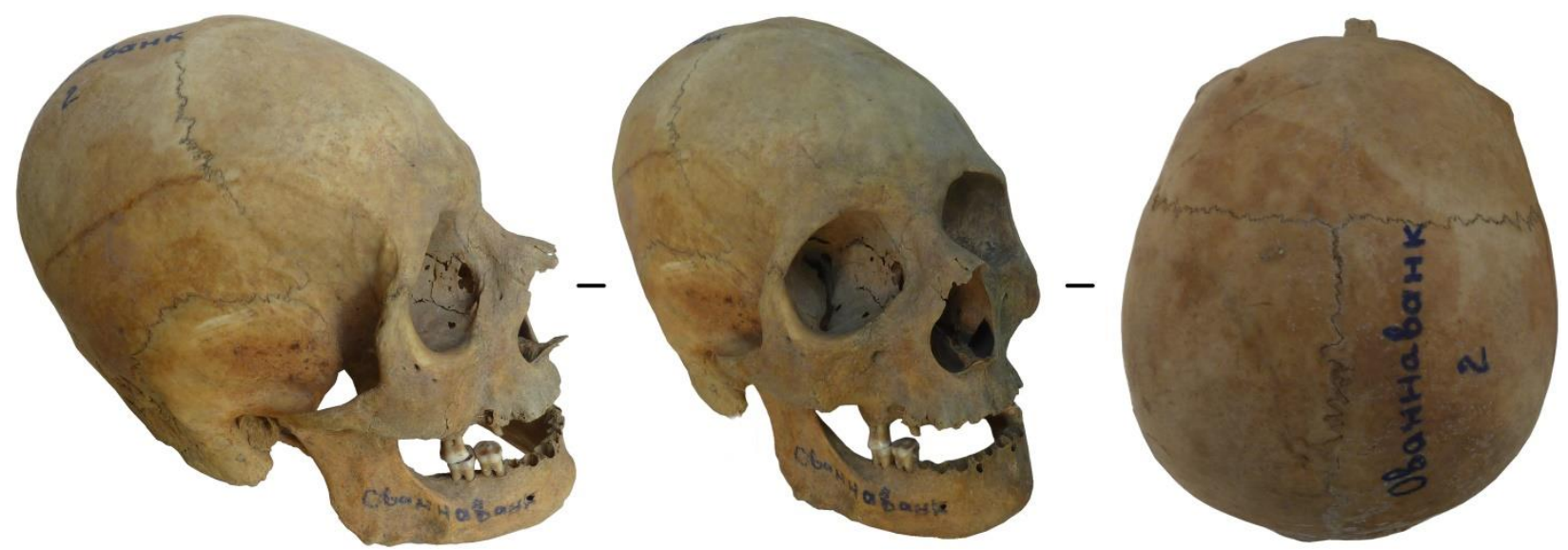

Рис. 3. Индивид № 2

Fig. 3. Individual No. 2
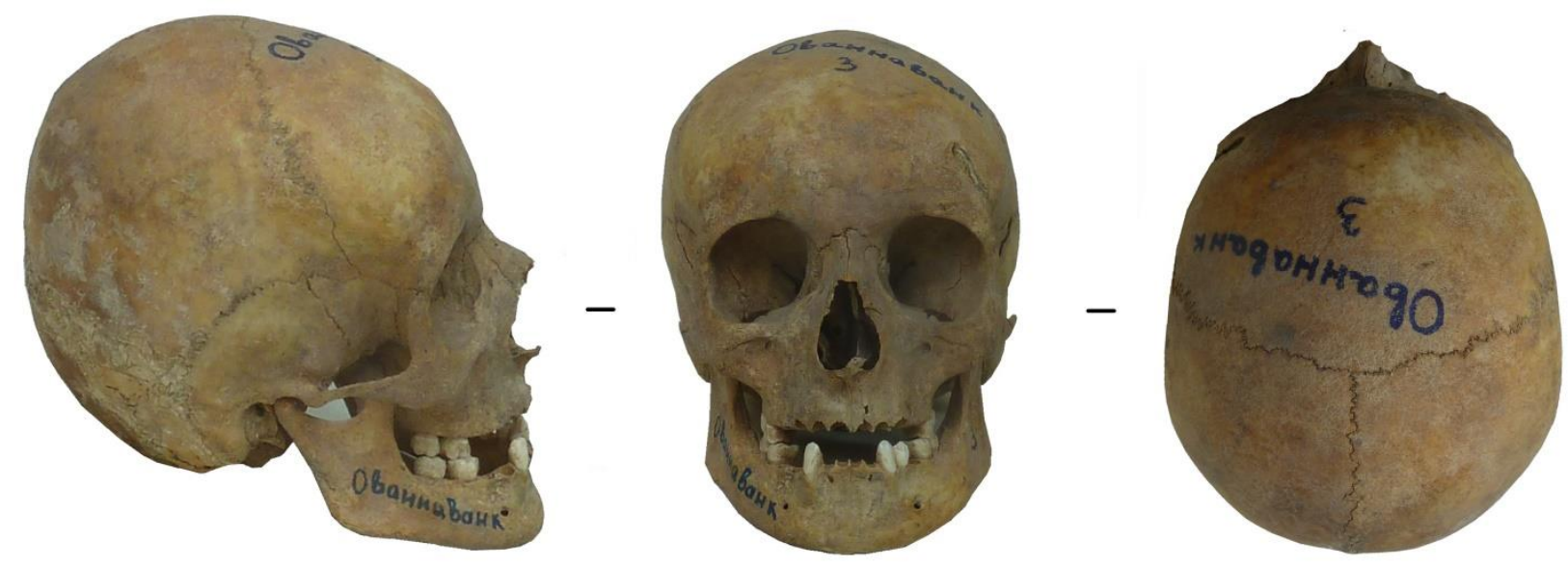

Рис. 4. Индивид № 3

Fig. 4. Individual No. 3
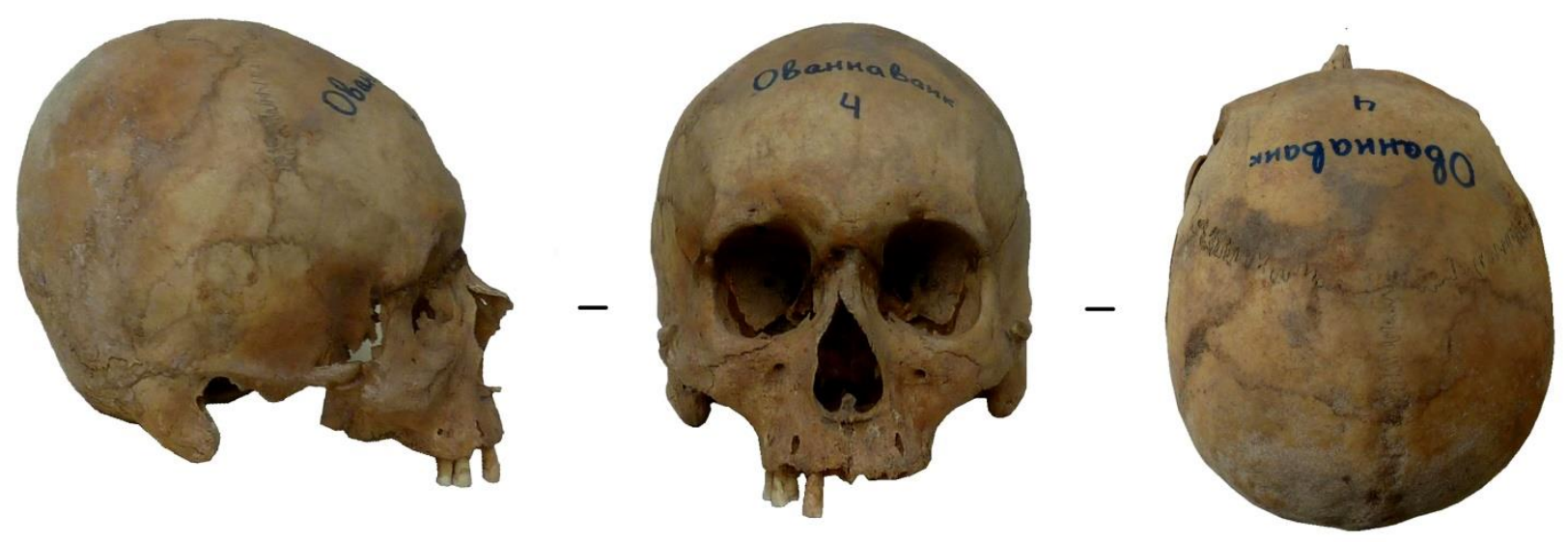

Рис. 5. Индивид № 4

Fig. 5. Individual No. 4 

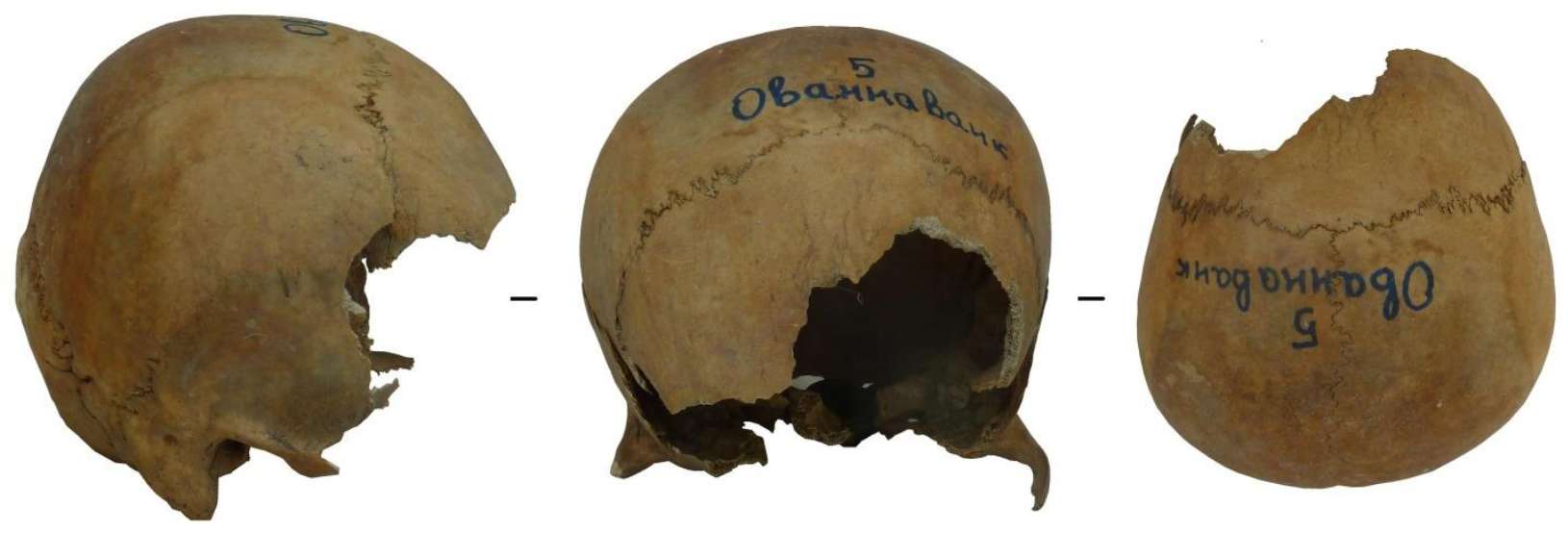

Рис. 6. Индивид № 5

Fig. 6. Individual No. 5
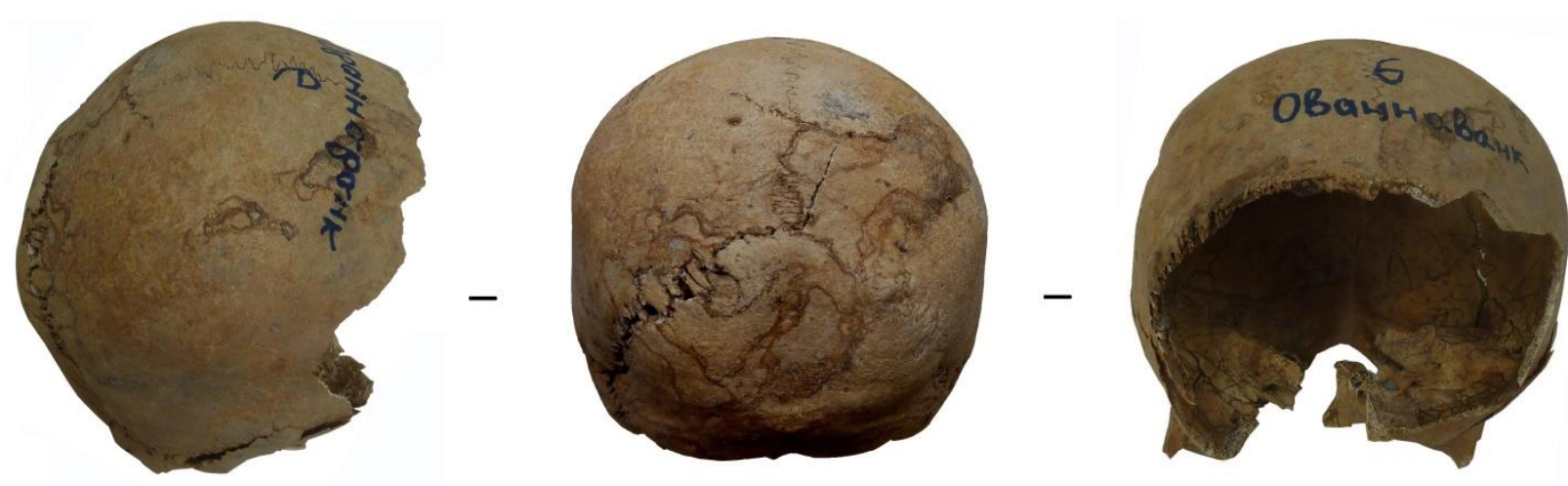

Рис. 7. Индивид № 6

Fig. 7. Individual No. 6

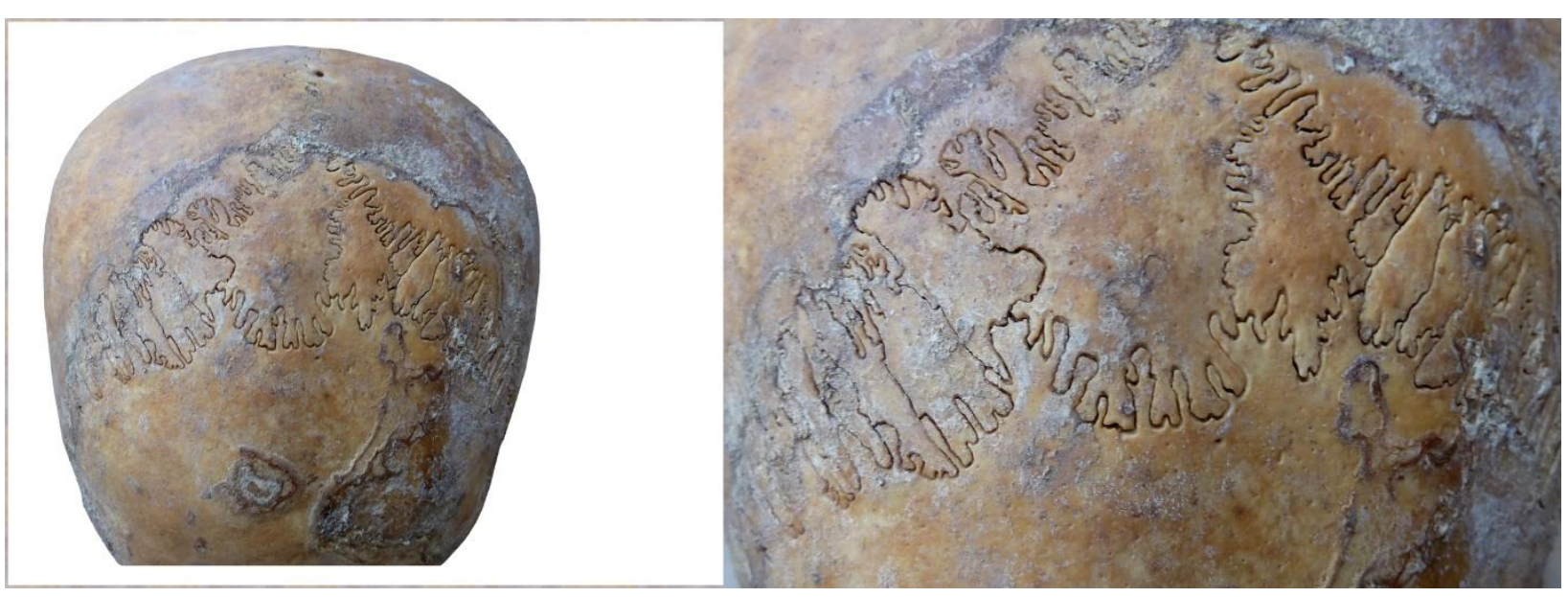

Pис. 8. Os Incae multipartitum, foramina parietalia

Fig. 8. Os Incae multipartitum, foramina parietalia 

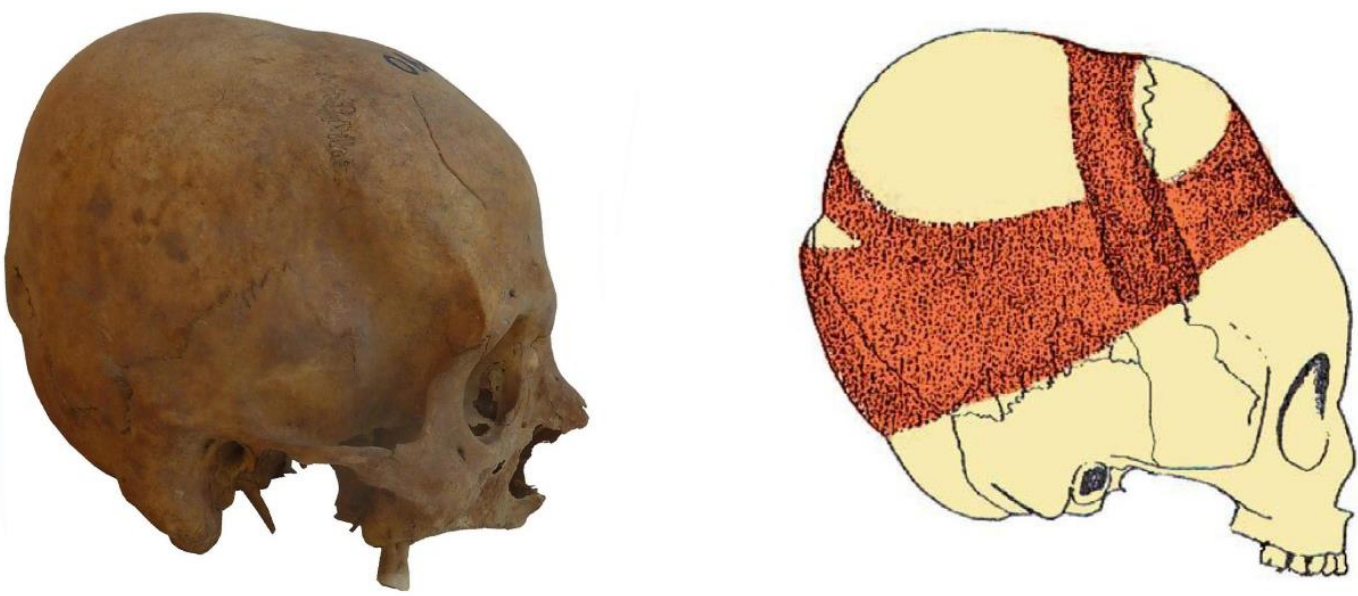

Рис. 9. Искусственная деформация черепа (индивид 1)

Fig. 9. Artificial deformation of the skull (individual 1)
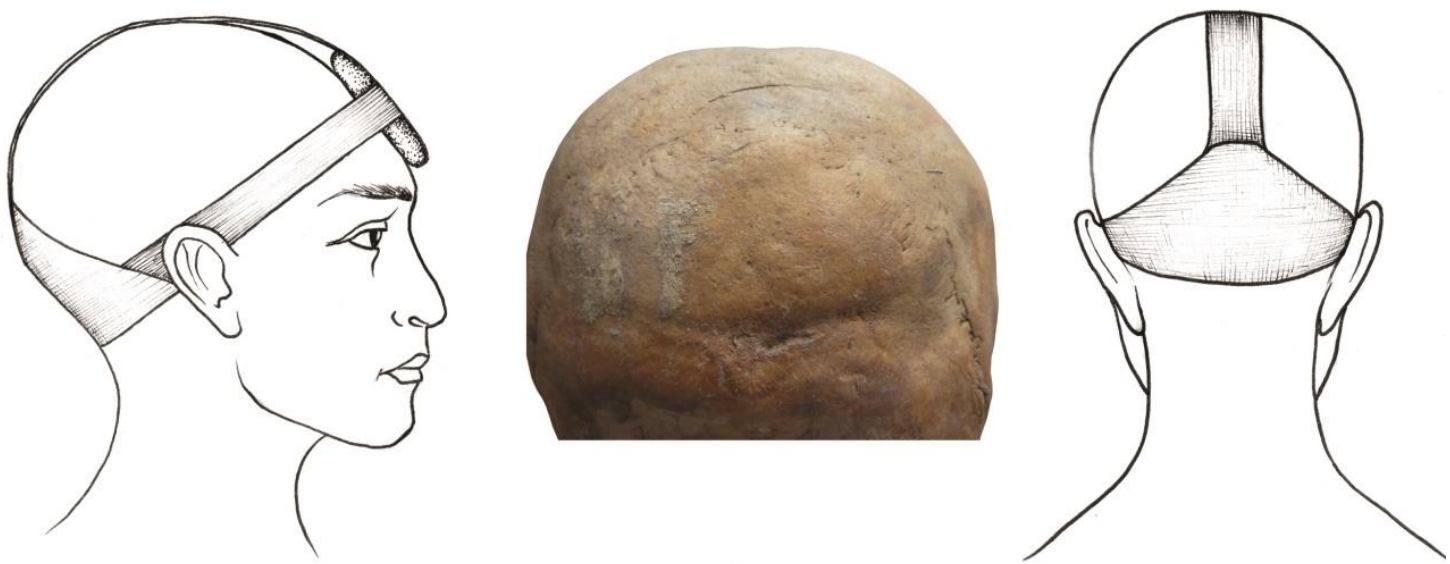

Рис. 10. Искусственная деформация черепа (индивид 1)

Fig. 10. Artificial deformation of the skull (individual 1)

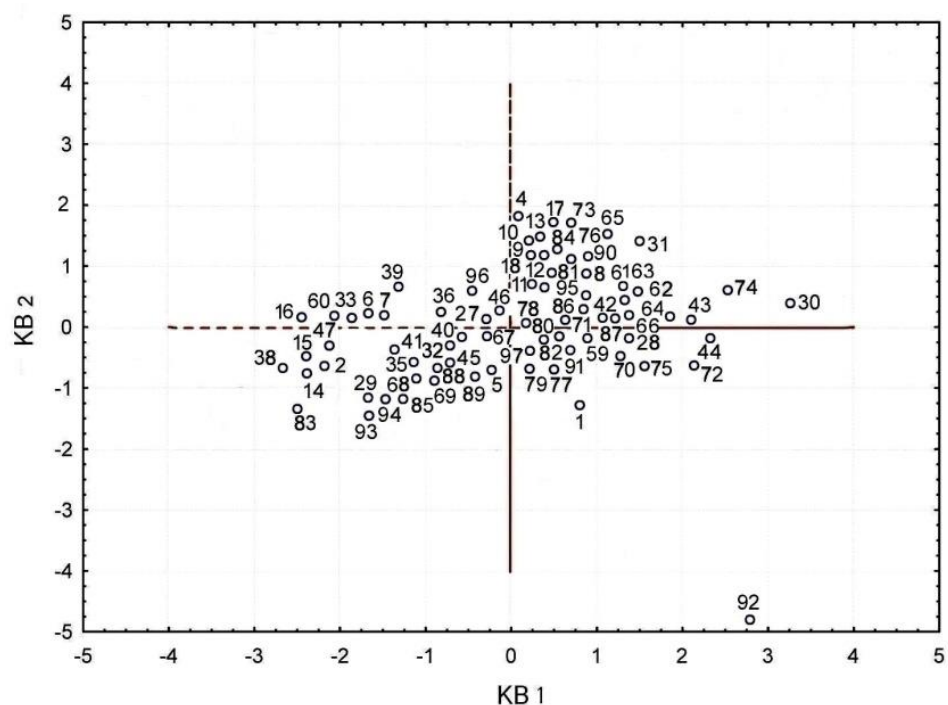

Рис. 11. Положение мужских краниологических серий в пространстве первого и второго канонических векторов. Номера серий в соответствии с табл. 3

Fig. 11. Position of male craniological series in the space of the first and second canonical vectors. Series numbers in accordance with Table. 3 


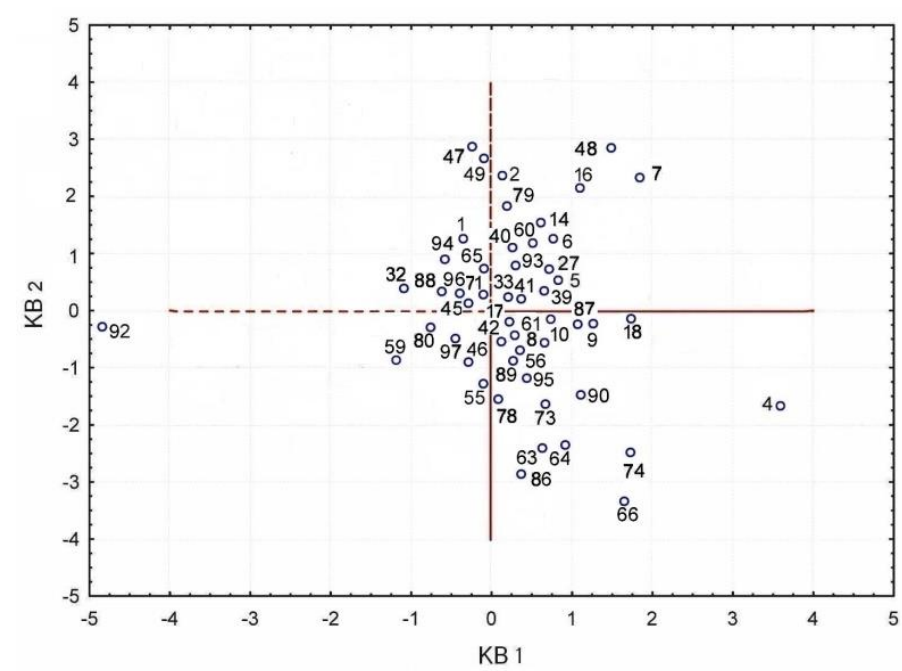

Рис. 12. Положение женских краниологических серий в пространстве первого и второго канонических векторов. Номера серий в соответствии с табл. 1

Fig. 12. Position of female craniological series in the space of the first and second canonical vectors.

Series numbers in accordance with Table 1

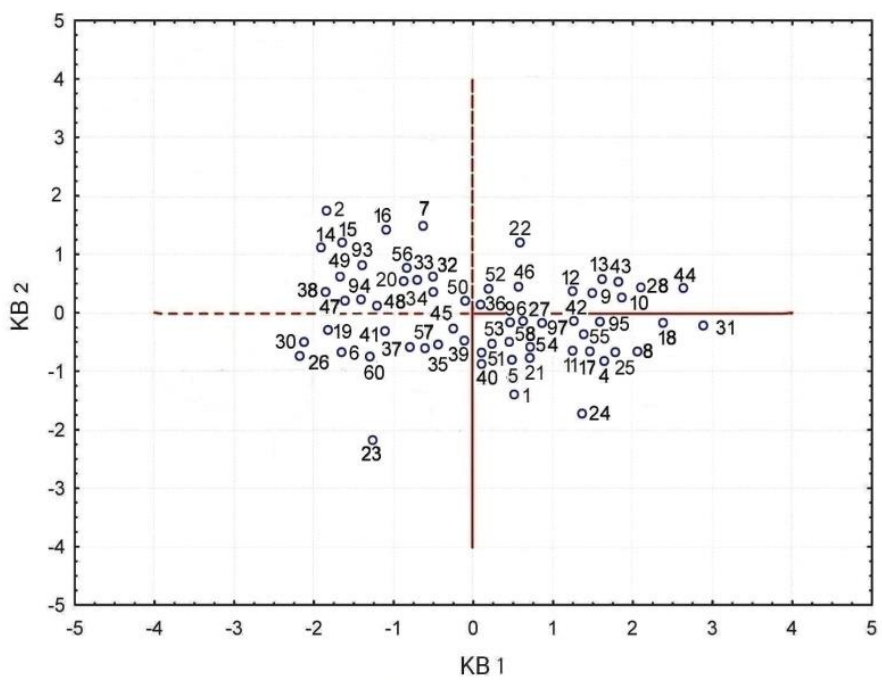

Рис. 13. Положение мужских краниологических серий в пространстве первого и второго канонических векторов. Номера серий в соответствии с табл. 1

Fig. 13. Position of male craniological series in the space of the first and second canonical vectors. Series numbers in accordance with Table 1

\section{Список литературы}

1. Абдушелишвили М.Г. 1964. Антропология древнего и современного населения Грузии. Тбилиси, Мецниереба, 206.

2. Абдушелишвили М.Г. 1972. Материалы совместных советско-индийских антропологических исследований в свете общих проблем генезиса индо-средиземноморской расы. Советская этнография. 6: 119-129.

3. Джавахишвили Э.Н. 1966. Сионская краниологическая серия. К краниологии древнего и современного населения Кавказа. Тбилиси, Мецниереба, 89-133.

4. Алексеев В.П. 1974. Происхождение народов Кавказа. М., Наука, 317.

5. Алексеев В.П., Дебец Г.Ф. 1964. Краниометрия (методика антропологических исследований). М., Наука, 128.

6. Алишан Г. 1890. Аздарар. Венеция, 173 (на арм. яз.).

7. Гаджиев А.Г. 1965. Происхождение народов Дагестана (по данным антропологии). Махачкала, 232. 
8. Геродот. 1986. История. Ереван, 890 (на арм. яз.).

9. Даврижеци А. 1891. Книга истории. Вагаршапат, 309 (на арм. яз.).

10. Дебец Г.Ф. 1956. Антропологические исследования в Дагестане. Труды Института этнографии. 33: 207-237.

11. Дьяченко В.И. 1988. Воспитание детей у якутов. Традиционное воспитания детей у народов Сибири. Вып. 8. Ленинград: 46-49.

12. Жиров Е.В. 1940. Об искусственной деформации головы. Краткие сообщения Института истории материальной культуры. 8: 81-88. 1: $292-296$.

13. Закарян Л.Д. 1973. Об одном рельефе Ованаванка. Историко-филологический журнал.

14. Зубов А.А. 1968а. Одонтология (методика антропологических исследований). М., Наука, 200.

15. Зубов А.А. 1968б. Некоторые данные одонтологии к проблеме эволюции человека и его pac. Проблемы эволюции человека и его рас. М.: 5-122.

16. Канакерци 3. 1870. Хроника. Том III. Вагаршапат, 300 (на арм. яз.).

17. Канакерци 3. 1969. Хроника. Перевод с арм. Предисл. и комм. М.О. ДарбинянМамиконян. М., 213 (на арм. яз.).

18. Кафадарян К. 1948. Ованаванк и его надписи. Ереван, НАН РА, 121 (на арм. яз.).

19. Костаньянц К. 1913. Лапидарная летопись. С.-Петербург, 207.

20. Козинцев А.Г. 1974. Проблема происхождения антропологических типов Северного Кавказа в свете данных археологии. Антропология и геногеография. М.: 198-214.

21. Натишвили А.Н., Абдушелишвили М.Г. 1955. Предварительные данные об антропологических исследованиях грузинского народа. Краткие сообщения Института этнографии. XXII: 60-71.

22. Новый словарь армянского языка (Айказян). 1981. Том II. Ереван, 1067 (на арм. яз.).

23. Манучарян А.Г. 2019. Эпиграфически-историографические исследования истории армянской церкви. Ереван, 301 (на арм. яз.).

24. Миклашевская Н.Н. 1959. Некоторые данные по палеоантропологии Дагестана. Материалы археологии Дагестана. 1: 89-110.

25. Мовсесян А.А., Мамонова Н.Н., Рычков Ю.Г. 1975. Программа и методика исследования аномалий черепа. Вопросы антропологии. 51: 127-150.

26. Овсепян Г. 1944. Материалы и исследования по истории армянского искусства и культуры. Том ІІІ. Нью-Йорк, 501 (на арм. яз.).

27. Орбели И.А. 1915. Надпись санаинского моста. Христианский Восток. IV (II): 191-194.

28. Попов А.Н., Чикашева Т.А., Шпакова Е.Г. 1997. Бойсманская археологическая культура Южного Приморья (по материалам многослойного памятника Бойсмана-2). Новосибирск, Наука, 95.

29. Тораманян Т. 1948. Материалы по истории армянской архитектуры. Том II. Ереван, 305 (на арм. яз.).

30. Трофимова Т.А. 1956. Антропологический состав населения г. Болгары в X-XV вв. Труды института этнологии. Антропологический сборник. XXXIII: 73-115.

31. Худавердян А.Ю. 2005. Атлас палеопатологических находок на территории Армении. Ереван, Ван Арьян, 286.

32. Худавердян А.Ю. 2016. Биоархеологические подходы к изучению следов искусственного воздействия на череп (на примере популяций эпохи бронзы и раннего железного века с территории Армении). Вестник археологии, антропологии и этнографии. 1 (32): 103-114.

33. Худавердян А.Ю., Жамкочян А.С., Акопян Н.Г. 2016. Население Ованнаванка в эпоху средневековья. Биологический журнал Армении НАН PA. 4 (LXIX): 13-21.

34. Худавердян А.Ю., Гаспарян Б.З., Пинхаси Р., Канаян А.С., Ованесян Н.А. 2017. Комплексное исследование антропологических материалов позднего энеолита из пещеры Арени 1. Вестник археологии, антропологии и этнографии. 2 (37): 72-93.

35. Худавердян А.Ю., Жамкочян А.С., Акопян Н.Г., Бабаян Ф.С., Енгибарян А.А., Хачатрян А.А., Еганян Л.Г. 2018. Антропологические особенности населения Армянского нагорья и этногенетическая ситуация на Южном Кавказе в эпоху средневековья. Вестник археологии, антропологии и этнографии. 1 (40): 60-88.

36. Шахазиз Е. 1987. История Аштарака. Ереван, 350 (на арм. яз.). 
37. Шевченко А.В. 1986. Антропология населения южнорусских степей в эпоху бронзы. Антропология современного и древнего населения Европейской части СССР. Л.: 121-215.

38. Aufderheide A.C., Rodríguez-Martín C. 1998. The Cambridge encyclopaedia of human palaeopathology. Cambridge, Cambridge University Press, 496.

39. Buikstra J.E., Ubelaker D.H. 1994. Standards of data collection from human skeletal remains. Fayetteville: Arkansas Archaeological Survey Research Series, 272.

40. Goodman A.H., Martin D.L., Armelagos G.J., Qark G. 1984. Indications of stress from bones and teeth. In: Paleopathology at the origins of agriculture. New York: 13-49.

41. Goodman A.H., Armelagos G.J. 1989. Infant and Childhood Morbidity and Mortality Risks in Archaeological Populations. In: World Archaeology. 21 (2): 225-243.

42. Hillson S. 1996. Dental anthropology. Cambridge, Cambridge University Press, 392.

43. Hershkovitz I., Greenwald C.M., Latimer B., Jellema L.M., Wish-Baratz S., Eshed V., Dutour O., Rothschild B.M. 2002. Serpens endocrania symmetrica (SES): a new term and possible clue for identifying intrathoracic disease in skeletal populations. In: American journal of Physical Anthropology. 118: 201-216.

44. Khudaverdyan A.Yu. 2011a. Artificial modification of skulls and teeth from ancient burials in Armenia. In: Anthropos. 106 (2): 602-609.

45. Khudaverdyan A.Yu. 2011b. Trepanation and artificial cranial deformations in ancient Armenia. In: Anthropological Review. 74 (1): 39-55.

46. Larsen C.S. 1997. Bioarchaeology: Interpreting Behavior from the Human Skeleton. Cambridge, 461.

47. Lewis M.E. 2004. Endocranial lesions in non-adult skeletons: understanding their aetiology. In: International Journal of Osteoarchaeology. 14: 82-97.

48. Nussinovitch M., Yoeli R., Elishkevitz K., Varsano I. 2004. Acute mastoiditis in children: Epidemiologic, clinical, microbiologic, and therapeutic aspects over past years. In: Clinical Pediatrics (Phila). 43: 261-267.

49. Ortner D.J. 2003. Identification of pathological conditions in human skeletal remains. 2nd edition. San Diego and London, Academic Press, 645.

50. Ortner D.J., Putschar W.G.J. 1981. Identification of Pathological Conditions in Humah Skeletal Remains. Washington, Smithonian Institution Press, 480.

\section{References}

1. Abdushelishvili M.G. 1964. Antropologiâ drevnego i sovremennogo naseleniâ Gruzii [Anthropology of the ancient and modern population of Georgia]. Tbilisi, Mecniereba, 206 (in Russian).

2. Abdushelishvili M.G. 1972. Materialy sovmestnykh sovetsko-indiyskikh antropologicheskikh issledovaniy $\mathrm{v}$ svete obshchikh problem genezisa indo-sredizemnomorskoy rasy [Materials of joint Soviet-Indian anthropological research in the light of general problems of the genesis of the IndoMediterranean race]. Sovetskaya etnografiya [Soviet ethnography]. 6: 119-129 (in Russian).

3. Dzhavakhishvili E.N. 1966. Sionskaya kraniologicheskaya seriya [Zion Craniological Series]. In: K kraniologii drevnego i sovremennogo naseleniya Kavkaza [On the craniology of the ancient and modern population of the Caucasus]. Tbilisi, Mecniereba, 89-133 (in Russian).

4. Alekseev V.P. 1974. Proiskhozhdeniye narodov Kavkaza [Origin of the peoples of the Caucasus]. M., Nauka, 317.

5. Alekseev V.P., Debets G.F. 1964. Kraniometriia: Metodika antropologicheskikh issledovanii [Craniometry (method of anthropological research)]. M., Nauka, 128 (in Russian).

6. Alishan G. 1890. Azdarar. Venetsiya, 173 (in Armenian).

7. Gadzhiyev A.G. 1965. Proiskhozhdeniye narodov Dagestana (po dannym antropologii) [The origin of the peoples of Dagestan (according to anthropology)]. Makhachkala, 232 (in Russian).

8. Herodot. 1986. Istoriya [History]. Yerevan, 890 (in Armenian).

9. Davrizhetsi A. 1891. Kniga istorii [History book]. Vagarshapat, 309 (in Armenian).

10. Debets G.F. 1956. Antropologicheskiye issledovaniya v Dagestane [Anthropological research in Dagestan]. In: Trudy Instituta etnografii [Proceedings of the Institute of Ethnography]. 33: 207-237 (in Russian). 
11. D'yachenko V.I. 1988. Vospitaniye detey u yakutov [Raising children among the Yakuts]. In: Traditsionnoye vospitaniya detey u narodov Sibiri [Traditional parenting among the peoples of Siberia]. Vyp. 8. Leningrad: 46-49 (in Russian).

12. Zhirov Ye.V. 1940. Ob iskusstvennoy deformatsii golovy [On artificial head deformation]. In: Kratkiye soobshcheniya Instituta istorii material'noy kul'tury [Brief reports of the Institute for the History of Material Culture]. 8: 81-88 (in Russian).

13. Zakaryan L.D. 1973. Ob odnom rel'yefe Ovanavanka [About one relief of Hovhannavank]. In: Istoriko-filologicheskiy zhurnal [Historical and Philological Journal]. 1: 292-296 (in Russian).

14. Zubov A.A. 1968a. Odontologiya (metodika antropologicheskikh issledovaniy) [Odontology (methodology of anthropological research)]. M., Nauka, 200 (in Russian).

15. Zubov A.A. 1968b. Nekotoryye dannyye odontologii k probleme evolyutsii cheloveka i yego ras [Some odontological data on the problem of the evolution of man and his races]. In: Problemy evolyutsii cheloveka i yego ras [Problems of evolution of man and his races]. M.: 5-122 (in Russian).

16. Kanakertsi Z. 1870. Khronika [Chronicle]. Tom III. Vagarshapat, 300 (in Armenian).

17. Kanakertsi Z. 1969. Khronika [Chronicle]. Perevod s arm. Predisloviye i kommentarii M.O. Darbinyan-Mamikonyan. M., 213 (in Armenian).

18. Kafadaryan K. 1948. Ovanavank i yego nadpisi [Hovhannavank and its inscriptions]. Yerevan, NAN RA, 121 (in Armenian). Russian).

19. Kostan'yants K. 1913. Lapidarnaya letopis' [Lapidary Chronicle]. S.-Peterburg, 207 (in

20. Kozintsev A.G. 1974. Problema proiskhozhdeniya antropologicheskikh tipov Severnogo Kavkaza $\mathrm{v}$ svete dannykh arkheologii [The problem of the origin of anthropological types of the North Caucasus in the light of archeological data]. In: Antropologiya i genogeografiya [Anthropology and genogeography]. M.: 198-214 (in Russian).

21. Natishvili A.N., Abdushelishvili M.G. 1955. Predvaritel'nyye dannyye ob antropologicheskikh issledovaniyakh gruzinskogo naroda [Preliminary data on anthropological studies of the Georgian people]. In: Kratkiye soobshcheniya Instituta etnografii [Brief reports of the Institute of Ethnography]. XXII: 60-71 (in Russian).

22. Novyy slovar' armyanskogo yazyka (Aykazyan) [New Dictionary of the Armenian Language (Haykazyan)]. 1981. Tom II. Yerevan, 1067 (in Armenian).

23. Manucharyan A.G. 2019. Epigraficheski-istoriograficheskiye issledovaniya istorii armyanskoy tserkvi [Epigraphic and Historiographic Studies of the History of the Armenian Church] . Yerevan, 301 (in Armenian).

24. Miklashevskaya N.N. 1959. Nekotoryye dannyye po paleoantropologii Dagestana [Some data on paleoanthropology of Dagestan]. In: Materialy arkheologii Dagestana [Archeological materials of Dagestan]. 1: 89-110 (in Russian).

25. Movsesyan A.A., Mamonova N.N., Rychkov Yu.G. 1975. Programma i metodika issledovaniya anomaliy cherepa [Program and methodology for the study of skull anomalies]. In: Voprosy antropologii [Anthropological issues]. 51: 127-150 (in Russian).

26. Ovsepyan G. 1944. Materialy i issledovaniya po istorii armyanskogo iskusstva i kul'tury [Materials and research on the history of Armenian art and culture]. Tom III. New York, 501 (in Armenian).

27. Orbeli I.A. 1915. Nadpis' sanainskogo mosta [Sanahin bridge inscription]. In: Khristianskiy Vostok [Christian East]. IV (II): 191-194 (in Russian).

28. Popov A.N., Chikasheva T.A., Shpakova Ye.G. 1997. Boysmanskaya arkheologicheskaya kul'tura Yuzhnogo Primor'ya (po materialam mnogosloynogo pamyatnika Boysmana-2) [Boisman archaeological culture of South Primorye (based on materials from the Boisman-2 multilayer site)]. Novosibirsk, Nauka, 95 (in Russian).

29. Toramanyan T. 1948. Materialy po istorii armyanskoy arkhitektury [Materials on the history of Armenian architecture]. Tom II. Yerevan, 305 (in Armenian).

30. Trofimova T.A. 1956. Antropologicheskiy sostav naseleniya g. Bolgary v X-XV vv. [Anthropological composition of the population of the city of Bulgar in the X-XV centuries.]. In: Trudy instituta etnologii. Antropologicheskiy sbornik [Proceedings of the Institute of Ethnology. Anthropological collection]. XXXIII: 73-115 (in Russian). 
31. Khudaverdyan A.Yu. 2005. Atlas paleopatologicheskikh nakhodok na territorii Armenii [Atlas of paleopathological findings in Armenia]. Yerevan, Van Ar'yan, 286 (in Russian).

32. Khudaverdyan A.Yu. 2016. Bioarkheologicheskiye podkhody $\mathrm{k}$ izucheniyu sledov iskusstvennogo vozdeystviya na cherep (na primere populyatsiy epokhi bronzy i rannego zheleznogo veka s territorii Armenii) [Bioarchaeological approaches to the study of traces of artificial impact on the skull (on the example of populations of the Bronze Age and the Early Iron Age from the territory of Armenia)]. In: Vestnik arkheologii, antropologii i etnografii [Bulletin of Archeology, Anthropology and Ethnography]. 1 (32): 103-114 (in Russian).

33. Khudaverdyan A.Yu., Zhamkochyan A.S., Akopyan N.G. 2016. Naseleniye Ovannavanka v epokhu srednevekov'ya [Population of Hovhannavank in the Middle Ages]. In: Biologicheskiy zhurnal Armenii NAN RA [Biological Journal of Armenia NAS RA]. 4 (LXIX): 13-21 (in Russian).

34. Khudaverdyan A.Yu., Gasparyan B.Z., Pinkhasi R., Kanayan A.S., Ovanesyan N.A. 2017. Kompleksnoye issledovaniye antropologicheskikh materialov pozdnego eneolita iz peshchery Areni 1 [Comprehensive study of anthropological materials of the late Eneolithic from the Areni 1 cave]. In: Vestnik arkheologii, antropologii i etnografii [Bulletin of Archeology, Anthropology and Ethnography]. 2: 72-93 (in Russian).

35. Khudaverdyan A.Yu., Zhamkochyan A.S., Akopyan N.G., Babayan F.S., Yengibaryan A.A., Khachatryan A.A., Yeganyan L.G. 2018. Antropologicheskiye osobennosti naseleniya Armyanskogo nagor'ya i etnogeneticheskaya situatsiya na Yuzhnom Kavkaze $\mathrm{v}$ epokhu srednevekov'ya [Anthropological characteristics of the population of the Armenian Highlands and the ethnogenetic situation in the South Caucasus in the Middle Ages]. In: Vestnik arkheologii, antropologii i etnografii [Bulletin of Archeology, Anthropology and Ethnography]. 1 (40): 60-88 (in Russian).

36. Shakhaziz Ye. 1987. Istoriya Ashtaraka [Ashtarak history]. Yerevan, 350 (in Armenian).

37. Shevchenko A.V. 1986. Antropologiya naseleniya yuzhno-russkikh stepey v epokhu bronzy [Anthropology of the population of the southern Russian steppes in the Bronze Age]. In: Antropologiya sovremennogo i drevnego naseleniya Yevropeyskoy chasti SSSR [Anthropology of the modern and ancient population of the European part of the USSR]. L.: 121-215 (in Russian).

38. Aufderheide A.C., Rodríguez-Martín C. 1998. The Cambridge encyclopaedia of human palaeopathology. Cambridge, Cambridge University Press, 496.

39. Buikstra J.E., Ubelaker D.H. 1994. Standards of data collection from human skeletal remains. Fayetteville: Arkansas Archaeological Survey Research Series, 272.

40. Goodman A.H., Martin D.L., Armelagos G.J., Qark G. 1984. Indications of stress from bones and teeth. In: Paleopathology at the origins of agriculture. New York: 13-49.

41. Goodman A.H., Armelagos G.J. 1989. Infant and Childhood Morbidity and Mortality Risks in Archaeological Populations. In: World Archaeology. 21 (2): 225-243.

42. Hillson S. 1996. Dental anthropology. Cambridge, Cambridge University Press, 392.

43. Hershkovitz I., Greenwald C.M., Latimer B., Jellema L.M., Wish-Baratz S., Eshed V., Dutour O., Rothschild B.M. 2002. Serpens endocrania symmetrica (SES): a new term and possible clue for identifying intrathoracic disease in skeletal populations. In: American journal of Physical Anthropology. 118: 201-216.

44. Khudaverdyan A.Yu. 2011a. Artificial modification of skulls and teeth from ancient burials in Armenia. In: Anthropos. 106 (2): 602-609.

45. Khudaverdyan A.Yu. 2011b. Trepanation and artificial cranial deformations in ancient Armenia. In: Anthropological Review. 74 (1): 39-55.

46. Larsen C.S. 1997. Bioarchaeology: Interpreting Behavior from the Human Skeleton. Cambridge, 461.

47. Lewis M.E. 2004. Endocranial lesions in non-adult skeletons: understanding their aetiology. In: International Journal of Osteoarchaeology. 14: 82-97.

48. Nussinovitch M., Yoeli R., Elishkevitz K., Varsano I. 2004. Acute mastoiditis in children: Epidemiologic, clinical, microbiologic, and therapeutic aspects over past years. In: Clinical Pediatrics (Phila). 43: 261-267.

49. Ortner D.J. 2003. Identification of pathological conditions in human skeletal remains. 2nd edition. San Diego and London, Academic Press, 645.

50. Ortner D.J., Putschar W.G.J. 1981. Identification of Pathological Conditions in Humah Skeletal Remains. Washington, Smithonian Institution Press, 480. 
Индивидуальные, средние размеры и указатели позднесредневековых черепов из Ованаванка Individual, average sizes and indexes of late medieval skulls from Hovhannavank

\begin{tabular}{|c|c|c|c|c|c|c|c|c|c|}
\hline $\begin{array}{c}\text { № по } \\
\text { Мартину } \\
\text { и др. }\end{array}$ & Признак & $\begin{array}{l}\text { I } \\
\text { q }\end{array}$ & $\begin{array}{l}\text { II } \\
\text { O }\end{array}$ & $\begin{array}{c}\text { III } \\
\text { 은 }\end{array}$ & $\begin{array}{r}\text { IV } \\
\hat{0}\end{array}$ & $\begin{array}{l}\mathrm{V} \\
\text { Q }\end{array}$ & $\begin{array}{l}\mathrm{VI} \\
\hat{0}\end{array}$ & o & 우 \\
\hline 1 & Продольный диаметр & 170 & 168 & 165 & 169 & - & - & 168.5 & 167.5 \\
\hline 8 & Поперечный диаметр & 147 & 133 & 140 & 140 & 145 & 142 & 138.4 & 144 \\
\hline $8: 1$ & Черепной указатель & 87.36 & 79.17 & 84.85 & 82.85 & - & - & 81.1 & 86.2 \\
\hline 17 & Высотный диаметр от ba & 133 & 134 & 142 & 135 & $125 ?$ & - & 134.5 & 133.4 \\
\hline $17: 1$ & $\begin{array}{l}\text { Высотно-продольный } \\
\text { указатель }\end{array}$ & 78.24 & 79.77 & 86,07 & 79.89 & - & - & 79.9 & 82.2 \\
\hline $17: 8$ & $\begin{array}{l}\text { Высотно-поперечный } \\
\text { указатель }\end{array}$ & 89.57 & 100.76 & 101,43 & 96.43 & 86.21 & - & 98.6 & 92.4 \\
\hline 20 & Высотный диаметр от ро & 117 & 119.8 & 117.9 & 115 & - & - & 117.4 & 117.5 \\
\hline $20: 1$ & $\begin{array}{l}\text { Высотно-продольный } \\
\text { указатель }\end{array}$ & 68.83 & 71.31 & 71.46 & 68.05 & - & - & 69.7 & 70.2 \\
\hline $20: 8$ & $\begin{array}{l}\text { Высотно-поперечный } \\
\text { указатель }\end{array}$ & 79.592 & 90.08 & 84.22 & 82.15 & - & - & 86.2 & 81.91 \\
\hline 5 & Длина основания черепа & 98.5 & 98 & 101.5 & 97 & - & - & 97.5 & 100 \\
\hline 9 & Наименьшая ширина лба & 91.5 & 97 & 103 & 89.2 & - & - & 93.1 & 97.3 \\
\hline $9: 8$ & $\begin{array}{l}\text { Лобно-поперечный ука- } \\
\text { затель }\end{array}$ & 61.62 & 72.94 & 73.58 & 63.72 & - & - & 68.33 & 67.6 \\
\hline 10 & Наибольшая ширина лба & 122 & 119 & 127 & 119 & - & - & 119 & 124.5 \\
\hline 11 & $\begin{array}{l}\text { Ширина основания че- } \\
\text { репа }\end{array}$ & 122 & 123 & 122 & 127 & 129 & 117 & 122.4 & 124.4 \\
\hline 11:8 & $\begin{array}{l}\text { Аурикулярно- } \\
\text { поперечный указатель }\end{array}$ & 82.99 & 92.49 & 87.15 & 90.72 & 88.9 & 82.39 & 88.6 & 86.4 \\
\hline 12 & Ширина затылка & 115 & $107.5 ?$ & 109 & 113 & 111 & 106 & 108.9 & 111.7 \\
\hline 29 & Лобная хорда & 111.5 & \begin{tabular}{|l|}
111.5 \\
\end{tabular} & 107 & 111.5 & - & - & 111.5 & 109.3 \\
\hline 30 & Теменная хорда & 104 & 101 & 108 & 102 & 103 & 111 & 104.7 & 105 \\
\hline 31 & Затылочная хорда & $96 ?$ & 100.5 & 92.5 & 102.8 & 94.2 & 93 & 98.8 & 94.3 \\
\hline 40 & Длина основания лица & 83.5 & 97.8 & 88 & 101 & - & - & 99.4 & 85.8 \\
\hline $40: 5$ & $\begin{array}{l}\text { Указатель выступания } \\
\text { лица }\end{array}$ & 84.78 & 99.796 & 86.69 & 104.13 & - & - & 101.97 & 85.8 \\
\hline 45 & Скуловой диаметр & 127.5 & 136 & 126.5 & 133 & - & - & 134.5 & 127 \\
\hline 48 & Bepx & 62.8 & 76 & 71 & 76.8 & - & - & 76.4 & 66.9 \\
\hline $45: 8$ & $\begin{array}{l}\text { Поперечный фациоцереб- } \\
\text { ральный указатель }\end{array}$ & 86.74 & 102.26 & 90.36 & 95 & - & - & 98.7 & 88.6 \\
\hline $9: 45$ & $\begin{array}{l}\text { Лобно-скуловой указа- } \\
\text { тель }\end{array}$ & 71.77 & 71.33 & 81.43 & 67.07 & - & - & 69.2 & 76.6 \\
\hline $48: 17$ & $\begin{array}{l}\text { Вертикальный фациоце- } \\
\text { ребральный указатель }\end{array}$ & 47.22 & 81.35 & 50 & 56.89 & & & 69.2 & 48.7 \\
\hline $48: 45$ & $\begin{array}{l}\text { Верхний лицевой указа- } \\
\text { тель }\end{array}$ & 49.26 & 55.89 & 56.13 & 57.75 & - & - & 56.83 & 52.7 \\
\hline 46 & Средняя ширина лица & 90.5 & 101.5 & 89.5 & 92 & - & - & $\begin{array}{c}96.8 \\
(2)\end{array}$ & $90(2)$ \\
\hline 60 & $\begin{array}{l}\text { Длина альвеолярной } \\
\text { дуги }\end{array}$ & $47 ?$ & 54 & 48 & $55 ?$ & - & - & 54.5 & 47.5 \\
\hline 61 & $\begin{array}{l}\text { Ширина альвеолярной } \\
\text { дуги }\end{array}$ & 52.8 & 61.8 & 60.5 & 60.5 & - & - & 61.2 & 56.7 \\
\hline
\end{tabular}


Via in tempore. История. Политология. 2021. Том 48, № 1 (65-96)

Via in tempore. History and political science. 2021. Volume 48, № 1 (65-96)

Окончание табл. 1

\begin{tabular}{|c|c|c|c|c|c|c|c|c|c|}
\hline 1 & 2 & 3 & 4 & 5 & 6 & 7 & 8 & 9 & 10 \\
\hline 62 & Длина неба & $37.8 ?$ & 43.7 & 38 & 49 & - & - & 46.4 & 37.9 \\
\hline 63 & Ширина неба & 31 & 35 & 31 & $34.5 ?$ & - & - & 34.8 & 31 \\
\hline $63: 62$ & Небный указатель & 82.02 & 80.092 & 81.58 & 70.41 & - & - & 75.3 & 81.8 \\
\hline 55 & Высота носа & 54 & 59 & 52 & 55 & - & - & 57 & 53 \\
\hline 54 & Ширина носа & $26 ?$ & 29 & 22 & 24 & - & - & 26.5 & 24 \\
\hline $54: 55$ & Носовой указатель & 48.15 & 49.16 & 42.31 & 43.64 & - & - & 46.4 & 45.3 \\
\hline 51 & Ширина орбиты от mf & 40.8 & 44 & 43 & $41 ?$ & - & - & 42.5 & 41.9 \\
\hline $51 \mathrm{a}$ & Ширина орбиты от d & 38 & 40 & 37.8 & 38 & - & - & 39 & 37.9 \\
\hline 52 & Высота орбиты & 35.5 & 35.5 & 36 & 38 & - & - & 36.8 & 35.8 \\
\hline $52: 51$ & Орбитный указатель (mf) & 87.01 & 80.69 & 83.73 & 92.69 & - & - & 86.7 & 85.4 \\
\hline $52: 51$ & Орбитный указатель (d) & 93.43 & 88.75 & 95.24 & 100 & - & - & 94.4 & 94.4 \\
\hline $\mathrm{MC}$ & $\begin{array}{l}\text { Максиллофронтальная } \\
\text { ширина }\end{array}$ & 16 & 21.8 & 21 & 18 & - & - & 19.9 & 18.5 \\
\hline MS & $\begin{array}{l}\text { Максиллофронтальная } \\
\text { высота }\end{array}$ & 9 & 11.5 & 10 & 10 & - & - & 10.8 & 9.5 \\
\hline MS:MC & $\begin{array}{l}\text { Максиллофронтальный } \\
\text { указатель }\end{array}$ & 56.25 & 52.76 & 47.62 & 55.56 & - & - & 54.2 & 51.94 \\
\hline $\mathrm{DC}$ & Дакриальная ширина & 18.5 & 27 & 27 & 22 & - & - & 24.5 & 22.8 \\
\hline DS & Дакриальная высота & 13 & 17.5 & 16 & 11.5 & - & - & 14.5 & 14.5 \\
\hline DS:DC & Дакриальный указатель & 70.28 & 64.82 & 59.26 & 52.28 & - & - & 58.6 & 64.8 \\
\hline SC & Симотическая ширина & 9 & 14.5 & 10.2 & 8.2 & - & - & 11.4 & 9.6 \\
\hline SS & Симотическая высота & 4.5 & 8 & 5 & 3.8 & - & - & 5.9 & 4.8 \\
\hline SS:SC & Симотический указатель & 50 & 55.18 & 49.02 & 46.35 & - & - & 50.8 & 49.6 \\
\hline $32 n$ & $\begin{array}{l}\text { Угол профиля лба от } \\
\text { назиона }\end{array}$ & 82 & 81 & 86 & 80 & - & - & 80.5 & 84 \\
\hline $32 \mathrm{gl}$ & $\begin{array}{l}\text { Угол профиля лба от } \\
\text { глабеллы }\end{array}$ & 80 & 75 & 82 & 71 & - & - & 73 & 81 \\
\hline 72 & Общий лицевой угол & $97 ?$ & 88 & 88 & 78 & - & - & 83 & 87.5 \\
\hline 73 & Средний лицевой угол & 92 & 87 & 84 & 79 & - & - & 83 & 88 \\
\hline 74 & Угол альвеолярной части & $99 ?$ & 99 & 98 & 77 & - & - & 88 & 98.5 \\
\hline $75(1)$ & Угол выступания носа & 31 & 34 & 32 & 32 & - & - & 33 & 31.5 \\
\hline 77 & Назомалярный угол & 139 & 135 & 131 & 145 & - & - & 140 & 135 \\
\hline$<\mathrm{zm}$ & Зигомаксиллярный угол & 125 & 126 & 126 & 125 & - & - & 125.5 & 125.5 \\
\hline $68(1)$ & Длина н.ч. от мыщелков & 99 & 93.8 & 103 & 108 & - & - & 100.9 & 101 \\
\hline 79 & Угол ветви н.ч. & 32.5 & 39 & 42 & 30.5 & - & - & 34.8 & 37.3 \\
\hline 68 & Длина н.ч. от углов & 73 & 73.8 & 73.2 & 80 & - & - & 76.9 & 73.1 \\
\hline 70 & Высота ветви & 60.5 & 61 & 52 & 68 & - & - & 64.5 & 56.3 \\
\hline $71 \mathrm{a}$ & $\begin{array}{l}\text { Наименьшая ширина } \\
\text { ветви }\end{array}$ & 27 & 30 & 29.2 & 32 & - & - & 31 & 28.1 \\
\hline 65 & Мыщелковая ширина & 114 & 116 & 114 & 120 & - & - & 118 & 114 \\
\hline 66 & Угловая ширина & 96 & 103 & 107 & 103 & - & - & 103 & 101.5 \\
\hline 67 & Передняя ширина & 43 & 41.8 & 43 & 50 & - & - & 45.9 & 43 \\
\hline 69 & Высота симфиза & 27 & 29.5 & 32.8 & 30 & - & - & 29.8 & 29.9 \\
\hline $69(1)$ & Высота тела & 21 & 26.8 & 23.5 & 27 & - & - & 26.9 & 22.3 \\
\hline $69(2)$ & Толщина тела & 11 & 12 & 13 & 17 & - & - & 14.5 & 12 \\
\hline 47 & Полная высота лица & $125 ?$ & 118.8 & 113.5 & 124.5 & - & - & 121.7 & 119.3 \\
\hline
\end{tabular}


Размеры зубов индивидов из Ованнаванка

Teeth sizes of individuals from Hovhannavank

\begin{tabular}{|c|c|c|c|c|c|c|c|c|}
\hline \multirow[b]{3}{*}{ I1 } & \multicolumn{8}{|c|}{$\begin{array}{c}\text { Нижняя челюсть } \\
\text { Вестибуло-лингвальный диаметр } \mathrm{VL}_{\mathrm{cor}}\end{array}$} \\
\hline & \multicolumn{2}{|c|}{$\begin{array}{l}\text { Индивид } 1 . \\
\text { прав. лев. }\end{array}$} & \multicolumn{2}{|c|}{$\begin{array}{c}\text { Индивид } 2 . \\
\text { прав. лев. }\end{array}$} & \multicolumn{2}{|c|}{$\begin{array}{c}\text { Индивид } 3 . \\
\text { прав. лев. }\end{array}$} & \multicolumn{2}{|c|}{$\begin{array}{c}\text { Индивид } 4 . \\
\text { прав. лев. }\end{array}$} \\
\hline & - & - & - & - & - & - & - & - \\
\hline I2 & - & - & - & - & - & - & - & - \\
\hline $\mathbf{C}$ & - & - & - & - & 7.6 & 7.9 & 8.1 & - \\
\hline P1 & - & - & - & 7.7 & - & 7.6 & 7.5 & 7.5 \\
\hline $\mathbf{P 2}$ & - & - & - & - & - & - & 7.9 & 7.8 \\
\hline M1 & - & - & - & - & 10.2 & 10 & 10.8 & 9.9 \\
\hline M2 & - & - & 9.4 & - & 9.9 & 9.9 & 10.4 & - \\
\hline \multirow[t]{2}{*}{ M3 } & 8.5 & 9 & 9.5 & 9.4 & - & - & - & - \\
\hline & \multicolumn{8}{|c|}{ Мезио-дистальный диаметр $\mathrm{MD}_{\text {cor }}$} \\
\hline I1 & - & - & - & - & - & - & - & - \\
\hline I2 & - & - & - & - & - & - & - & - \\
\hline $\mathbf{C}$ & - & - & - & - & 6.8 & 6.8 & 6.8 & - \\
\hline P1 & - & - & - & 6.2 & - & 7.3 & 6.9 & 6.5 \\
\hline $\mathbf{P 2}$ & - & - & - & - & - & - & 7.1 & 6.8 \\
\hline M1 & - & - & - & - & 10.8 & 10.8 & 11.2 & $10.1 ?$ \\
\hline M2 & - & - & 10.7 & - & 11 & 11 & 10.3 & - \\
\hline \multirow[t]{2}{*}{ M3 } & $7.9 ?$ & 10.1 & 10.8 & 10.5 & - & - & - & - \\
\hline & \multicolumn{8}{|c|}{ Высота коронки $\mathrm{H}_{\text {cor }}$} \\
\hline M1 & - & - & - & - & 7.1 & 7.6 & 3.7 & - \\
\hline M2 & - & - & 4.5 & - & 7.1 & 7.6 & 3 & 5.2 \\
\hline \multirow[t]{2}{*}{ M3 } & 3.8 & 5.1 & 3.3 & 3.5 & - & - & - & - \\
\hline & \multicolumn{8}{|c|}{ Мезио-дистальный диаметр шейки $\mathrm{MD}_{\text {col }}$} \\
\hline M1 & - & - & - & - & 8.3 & 8.5 & 8.7 & - \\
\hline M2 & - & - & 7.8 & - & 9.8 & 9.3 & 8.6 & 8.9 \\
\hline \multirow[t]{2}{*}{ M3 } & - & - & 8.9 & 8.9 & - & - & - & - \\
\hline & \multicolumn{8}{|c|}{ Площада коронки MD × VL } \\
\hline M1 & - & - & - & - & 110.16 & 108 & 120.96 & 99.99 \\
\hline M2 & - & - & 100.58 & - & 108.9 & 108.9 & 107.12 & - \\
\hline \multirow[t]{2}{*}{ M3 } & 67.15 & 90.9 & 102.6 & 98.7 & - & - & - & - \\
\hline & \multicolumn{8}{|c|}{ Индекс коронки I $\mathrm{I}_{\text {cor }}(\mathrm{VL} / \mathrm{MD}) \times 100$} \\
\hline M1 & - & - & - & - & 94.45 & 92.6 & 96.43 & 98.02 \\
\hline M2 & - & - & 87.86 & - & 90 & 96.43 & 100.98 & - \\
\hline \multirow[t]{2}{*}{ M3 } & 107.6 & 89.11 & 87.97 & 89.53 & - & - & - & - \\
\hline & \multicolumn{8}{|c|}{$\begin{array}{l}\text { Модуль коронки } \mathrm{m}_{\mathrm{cor}} \\
\text { MD + VL / } 2\end{array}$} \\
\hline M1 & - & - & - & - & 10.5 & 10.4 & 11 & 10 \\
\hline M2 & - & - & 10.05 & - & 10.45 & 10.45 & 10.35 & - \\
\hline \multirow[t]{3}{*}{ M3 } & 8.2 & 9.55 & 10.15 & 9.95 & - & - & - & - \\
\hline & \multicolumn{8}{|c|}{$\begin{array}{c}\text { Верхняя челюсть } \\
\text { Вестибуло-лингвальный диаметр VL } L_{c o r}\end{array}$} \\
\hline & \multicolumn{2}{|c|}{ прав. лев. } & \multicolumn{2}{|c|}{ прав. лев. } & \multicolumn{2}{|c|}{ прав. лев. } & прав & лев. \\
\hline I1 & - & - & - & - & - & - & - & - \\
\hline I2 & - & - & - & - & - & - & 6.5 & 6.3 \\
\hline $\mathrm{C}$ & - & - & - & - & - & - & 8.2 & 8.6 \\
\hline
\end{tabular}


Via in tempore. История. Политология. 2021. Том 48, № 1 (65-96)

Via in tempore. History and political science. 2021. Volume 48, № 1 (65-96)

Окончание табл. 2

\begin{tabular}{|c|c|c|c|c|c|c|c|c|}
\hline 1 & 2 & 3 & 4 & 5 & 6 & 7 & 8 & 9 \\
\hline $\mathbf{P 1}$ & - & - & - & - & - & - & 8.9 & 8.8 \\
\hline $\mathbf{P 2}$ & - & - & - & - & - & - & 8.8 & - \\
\hline M1 & - & - & - & - & 11 & 11.5 & - & - \\
\hline M2 & - & - & 10.2 & 10.2 & 12.2 & 12 & - & - \\
\hline \multirow[t]{2}{*}{ M3 } & 10 & - & - & - & - & - & - & - \\
\hline & \multicolumn{8}{|c|}{ Мезио-дистальный диаметр MD $_{\text {cor }}$} \\
\hline I1 & - & - & - & - & - & - & - & - \\
\hline $\mathbf{I 2}$ & - & - & - & - & - & - & 6.7 & 6.5 \\
\hline $\mathbf{C}$ & - & - & - & - & - & - & 6.7 & 6.2 \\
\hline $\mathbf{P 1}$ & - & - & - & - & - & - & 6.9 & 6.3 \\
\hline $\mathbf{P 2}$ & - & - & - & - & - & - & 5.6 & - \\
\hline M1 & - & - & - & - & 10.6 & 10.7 & - & - \\
\hline M2 & - & - & 8.8 & $8.7 ?$ & 9.9 & 9.8 & - & - \\
\hline \multirow[t]{2}{*}{ M3 } & 7.9 & - & - & - & - & - & - & - \\
\hline & \multicolumn{8}{|c|}{ Высота коронки $\mathrm{H}_{\text {cor }}$} \\
\hline M1 & - & - & - & - & 6 & 6.9 & - & - \\
\hline M2 & - & - & 4.5 & 4.4 & 7.2 & 7 & - & - \\
\hline \multirow[t]{2}{*}{ M3 } & 4.8 & - & - & - & - & - & - & - \\
\hline & \multicolumn{8}{|c|}{ Мезио-дистальный диаметр шейки $\mathrm{MD}_{\text {col }}$} \\
\hline M1 & - & - & - & - & 6.5 & 7.5 & - & - \\
\hline M2 & - & - & 7.4 & $7.3 ?$ & 7.8 & 8.5 & - & - \\
\hline \multirow[t]{2}{*}{ M3 } & 6.2 & - & - & - & - & - & - & - \\
\hline & \multicolumn{8}{|c|}{ Площада коронки MD × VL } \\
\hline M1 & - & - & - & - & 116.6 & 120.05 & - & - \\
\hline M2 & - & - & 89.76 & 88.74 & 120.78 & 117.6 & - & - \\
\hline \multirow[t]{2}{*}{ M3 } & 79 & - & - & - & - & - & - & - \\
\hline & \multicolumn{8}{|c|}{ Индекс коронки $\mathrm{I}_{\text {cor }}(\mathrm{VL} / \mathrm{MD}) \times 100$} \\
\hline M1 & - & - & - & - & 103.78 & 107.48 & - & - \\
\hline M2 & - & - & 115.91 & 117.25 & 123.24 & 122.45 & - & - \\
\hline \multirow[t]{2}{*}{ M3 } & 126.6 & - & - & - & - & - & - & - \\
\hline & \multicolumn{8}{|c|}{ Модуль коронки $\mathrm{m}_{\mathrm{cor}} \mathrm{MD}+\mathrm{VL} / 2$} \\
\hline M1 & - & - & - & - & 10.8 & 11.1 & - & - \\
\hline M2 & - & - & 9.5 & 9.45 & 11.5 & 10.9 & - & - \\
\hline M3 & 8.95 & - & - & - & - & - & - & - \\
\hline
\end{tabular}

Таблица 3

Table 3

Список серий, привлеченных к сравнительному анализу

List of series involved in comparative analysis

\begin{tabular}{|c|l|c|}
\hline \multicolumn{1}{|c|}{ Регион, местность, серия } & Датировка \\
\hline 1 & Двин & V-VI вв. \\
\hline 2 & Армавир & XII-XIII вв. \\
\hline 3 & Бюракн /деформированные черепа/ & XII-XIII вв. \\
\hline 4 & Ованнаванк & - \\
\hline 5 & Гарни & ранне-феодальный период \\
\hline 6 & Бениамин & II-III в. \\
\hline 7 & Грузия: Самтавро & IV-IX вв. /ранне- \\
& феодальный период/ \\
\hline 8 & Грузия: Рустави & поздне-феодальный период \\
\hline 9 & Грузия: Душети & - \\
\hline
\end{tabular}


Продолжение табл. 3

\begin{tabular}{|c|c|c|}
\hline 1 & 2 & 3 \\
\hline 10 & Грузия: Хевсури & - \\
\hline 11 & Грузия: Сиони I & VII-X вв. \\
\hline 12 & Грузия: Сиони II & XII-XIII вв. \\
\hline 13 & Грузия: Сиони III & XVII-XVIII вв. \\
\hline 14 & Мингечаур I /катакомбные погребения /без деформ. черепа/ & I-VII вB. \\
\hline 15 & Мингечаур II /катакомбные погребения /слабо деформ. черепа/ & - \\
\hline 16 & Мингечаур III /катакомбные погребения /сильно деформ. черепа/ & - \\
\hline 17 & Мингечаур IV //погребения христианского типа/ & VII-IX вв. \\
\hline 18 & Самухский р-н Азербайджана /погребения мусульманского типа/ & XIV-XVII вв. \\
\hline 19 & Месопотамия: Ниппур & IX-X вв. \\
\hline 20 & Месопотамия: Тель Губба & Исламское время \\
\hline 21 & Месопотамия: Тель Сонгар & Исламское время \\
\hline 22 & Месопотамия: Ассур & Исламское время \\
\hline 23 & Турция: Богазкой & V-XI вв. \\
\hline 24 & Иран: Шах Тепе & VIII-X вв. \\
\hline 25 & Иран Туранг Тепе & $\mathrm{X}$ вв. \\
\hline 26 & Израиль: Бедунны & XVII-XVIII вв. \\
\hline 27 & Дагестан: Верхний Чир-Юрт & V-VII вв. \\
\hline 28 & Дагестан: Гоцатль & VIII-X вв. \\
\hline 29 & Дагестан: Дегва & - \\
\hline 30 & Дагестан: Узунтала & IX-XI вв. \\
\hline 31 & Дагестан: Миатли & XII-XIII вв. \\
\hline 32 & Краснодарский край: Гамовское и ближайшие ущелья & V-VII вв. \\
\hline 33 & Краснодарский край: Жукова & XIII-XIV вв. \\
\hline 34 & Краснодарский край: Ильичевское городище & XIV-XVI вв. \\
\hline 35 & Краснодарский край: храм у с. Веселое, склеп & IX-XI вв. \\
\hline 36 & Краснодарский край: храм у с. Веселое, некрополь храма & - \\
\hline 37 & Краснодарский край: храм у с. Веселое, наос храма & - \\
\hline 38 & Краснодарский край: храм у с. Веселое, притворы храма & - \\
\hline 39 & Карачаево-Черкесия: ранняя группа & III-V вB. \\
\hline 40 & Карачаево-Черкесия: поздняя группа & VIII-XII вв. \\
\hline 41 & Карачаево-Черкесия: Нижний Архыз & - \\
\hline 42 & Кабардино-Балкария: Чегем & XIV-XV вв. \\
\hline 43 & Кабардино-Балкария: Нижний Джулат & - \\
\hline 44 & Северная Осетия: Моздок & XII-XIV вв. \\
\hline 45 & Северная Осетия: Змейская & X-XII вв. \\
\hline 46 & Северная Осетия: Верхний Джулат & XIV-XVII вв. \\
\hline 47 & Северная Осетия: Мамисондон (сум.) & VIII-X вв. \\
\hline 48 & Северная Осетия: холм-1 & - \\
\hline 49 & Северная Осетия: ОЧМ & - \\
\hline 50 & Северная Осетия: Дзавгис-15 & XIV-XVI вв. \\
\hline 51 & Северная Осетия: Дзавгис-18 & - \\
\hline 52 & Северная Осетия: Дзавгис-21 & - \\
\hline 53 & Северная Осетия: Дзавгис-3 & - \\
\hline 54 & Северная Осетия: Верхняя Кобан & XIV-XVI вв. \\
\hline 55 & Осетия: Харх & X-XIII вв. \\
\hline 56 & Чечено-Ингушетия: Дуба-Юрт & IX-X вв. \\
\hline 57 & Чечено-Ингушетия: Кели-1 & XIV-XVI вв. \\
\hline 58 & Чечено-Ингушетия: Кели-2 & - \\
\hline 59 & Ставропольский край: Маджары & XIV-XV вв. \\
\hline
\end{tabular}


Окончание табл. 3

\begin{tabular}{|c|c|c|}
\hline 1 & 2 & 3 \\
\hline 60 & Северо-Западный Кавказ: Мощевая Балка & VI-VIII вв. \\
\hline 61 & Нижнего Поволжья, Нижнего Подонья & II-IV вв. \\
\hline 62 & - & V-VII в. \\
\hline 63 & - & VII-IX (X) вв. \\
\hline 64 & Астраханская область: Бугор Вакуровский & XIV в. \\
\hline 65 & Астраханская область: Маячный II & - \\
\hline 66 & Астраханская область: Самосделка & XVI в. \\
\hline 67 & Волжская Булгария: г. Биляр & X-XIII вв. \\
\hline 68 & Волжская Булгария: г. Булгар, «Бабий бугор»: суммарно & $\mathrm{X}-\mathrm{XV}$ вв. \\
\hline 69 & Волжская Булгария: г. Булгар, «Рядовой» & - \\
\hline 70 & Волжская Булгария: г. Булгар, «Четырехугольник» & X-XIII вв. \\
\hline 71 & Волжская Булгария: г. Булгар, «Минарет» & XIII-XV вв. \\
\hline 72 & Волжская Булгария: г. Булгар, «Культурный слой» & - \\
\hline 73 & Волжская Булгария: г. Булгар, «Греческая палата» & XIV вв. \\
\hline 74 & Средняя Волга: Ханская усыпальница & XIV-XV вв. \\
\hline 75 & Средняя Волга: Четырехугольник 1 & X-XIII вв. \\
\hline 76 & Средняя Волга: Четырехугольник 2 & XIII-XV вв. \\
\hline 77 & Средняя Волга: Четырехугольник 3 & X-XII вв. \\
\hline 78 & Средняя Волга: 1 Старокуйбышевский & эпоха до Золотой Орды \\
\hline 79 & Средняя Волга: 1 Старокуйбышевский & эпоха Золотой Орды \\
\hline 80 & Средняя Волга: Измерский & XI-XIII вв. \\
\hline 81 & Средняя Волга: Такталачукский & XIII-XIV вв. \\
\hline 82 & Средняя Волга: Азметьевский & - \\
\hline 83 & Средняя Волга: Барбашина Поляна & - \\
\hline 84 & Средняя Волга: г. Болгары (Р 45) & - \\
\hline 85 & Средняя Волга: Муромский городок & X-XIII вв. \\
\hline 86 & Средняя Волга: Мавзолеи г. Болгара & - \\
\hline 87 & Средняя Волга: Памятный знак & - \\
\hline 88 & Средняя Волга: район бывшего аэродрома & - \\
\hline 89 & Средняя Волга: каменный мавзолей (CLXXIV) & - \\
\hline 90 & Средняя Волга: северная часть Болгарского городища (CXCI) & - \\
\hline 91 & Волго-Уралье: Букеевская степь & XIV в. \\
\hline 92 & Украина: Чигирин & XVI-XVII в. \\
\hline 93 & Западная Украина & черняховская культура \\
\hline 94 & Дунайско-Днестровский регион: Буджак & - \\
\hline 95 & Молдова: Старый Орхей-1 & XIV в. \\
\hline 96 & Молдова: Старый Орхей-2 & XV в. \\
\hline 97 & Молдова: Старый Орхей-3 & XVI-XVII вв \\
\hline
\end{tabular}

Таблица 4

Table 4

Элементы первых трех канонических векторов (КВ). Мужчины Elements of the first three canonical vectors $(\mathrm{CV})$. Men

\begin{tabular}{|c|c|c|c|c|}
\hline № по Мартину $и д p$. & Признак & КВ I & КВ II & КВ III \\
\hline 1 & Продольный диаметр & $\underline{-0,579}$ & $-0,121$ & 0,355 \\
\hline 8 & Поперечный диаметр & $\underline{0,819}$ & 0,215 & $-0,245$ \\
\hline 17 & Высотный диаметр & $-0,304$ & 0,182 & $-0,232$ \\
\hline 9 & Наименьшая ширина лба & $-0,584$ & 0,347 & $-0,176$ \\
\hline 45 & Скуловая ширина & 0,306 & $-0,173$ & $-0,199$ \\
\hline 48 & Верхняя высота лица & 0,016 & $-0,003$ & 0,200 \\
\hline
\end{tabular}


Окончание табл. 4

\begin{tabular}{|c|c|c|c|c|}
\hline 1 & 2 & 3 & 4 & 5 \\
\hline 55 & Высота носа & 0,156 & $-0,064$ & $-0,015$ \\
\hline 54 & Ширина носа & 0,052 & 0,344 & 0,190 \\
\hline 51 & Ширина орбиты от $\mathrm{mf}$ & 0,289 & 0,080 & 0,170 \\
\hline 52 & Высота орбиты & $-0,208$ & 0,645 & $-0,043$ \\
\hline 77 & Назомалярный угол & $-0,034$ & 0,158 & 0,294 \\
\hline $\mathrm{zm}$ & Зигомаксиллярный угол & 0,119 & 0,095 & 0,518 \\
\hline $\mathrm{SS}: \mathrm{SC}$ & Симотический указатель & 0,002 & 0,291 & 0,365 \\
\hline $75(1)$ & Угол выступания носа & $-0,260$ & 0,207 & $\underline{-0,736}$ \\
\hline \multicolumn{2}{|l|}{ Доля в общей дисперсии (\%) } & 29,970 & 23,369 & 13,291 \\
\hline
\end{tabular}

Таблица 5

Table 5

Элементы первых трех канонических векторов (КВ). Женщины

Elements of the first three canonical vectors (CV). Women

\begin{tabular}{|c|c|c|c|c|}
\hline № по Мартину $u д p$. & Признак & КВ I & КВ II & КВ III \\
\hline 1 & Продольный диаметр & 0,034 & $\underline{0,582}$ & 0,503 \\
\hline 8 & Поперечный диаметр & 0,095 & $\underline{-0,799}$ & $-0,464$ \\
\hline 17 & Высотный диаметр & 0,240 & 0,151 & $-0,220$ \\
\hline 9 & Наименьшая ширина лба & $-0,102$ & $\underline{0,551}$ & $-0,100$ \\
\hline 45 & Скуловая ширина & $-0,038$ & 0,029 & 0,130 \\
\hline 48 & Верхняя высота лица & $\underline{-0,645}$ & $-0,056$ & 0,216 \\
\hline 55 & Высота носа & $\underline{0,699}$ & 0,017 & $-0,035$ \\
\hline 54 & Ширина носа & 0,167 & $-0,094$ & 0,115 \\
\hline 51 & Ширина орбиты от mf & $-0,016$ & $-0,317$ & $-0,126$ \\
\hline 52 & Высота орбиты & $\underline{0,705}$ & 0,040 & $-0,116$ \\
\hline 77 & Назомалярный угол & 0,160 & $-0,108$ & 0,330 \\
\hline zm & Зигомаксиллярный угол & 0,179 & $-0,173$ & 0,399 \\
\hline SS:SC & Симотический указатель & 0,065 & $-0,105$ & 0,444 \\
\hline $75(1)$ & Угол выступания носа & 0,183 & $\underline{0,561}$ & $\underline{-0,686}$ \\
\hline Доля в общей дисперсии (\%) & 43,854 & 21,460 & 9,423 \\
\hline
\end{tabular}

Таблица 6

Table 6

Элементы первых трех канонических векторов (КВ). Мужчины Elements of the first three canonical vectors (CV). Men

\begin{tabular}{|c|c|c|c|c|}
\hline № по Мартину $\boldsymbol{u} \partial p$. & Признак & КВ I & КВ II & KB III \\
\hline 1 & Продольный диаметр & $\underline{-0,767}$ & 0,147 & 0,065 \\
\hline 8 & Поперечный диаметр & $\underline{0,803}$ & $-0,255$ & $-0,300$ \\
\hline 17 & Высотный диаметр & 0,030 & 0,300 & 0,231 \\
\hline 9 & Наименьшая ширина лба & $-0,289$ & $-0,306$ & 0,164 \\
\hline 45 & Скуловая ширина & 0,229 & $-0,101$ & $\underline{0,861}$ \\
\hline 48 & Верхняя высота лица & $-0,031$ & $-0,217$ & $\underline{0,585}$ \\
\hline 55 & Высота носа & 0,062 & $\underline{0,520}$ & $-0,293$ \\
\hline 54 & Ширина носа & 0,100 & $-0,174$ & $-0,139$ \\
\hline 51 & Ширина орбиты от $\mathrm{mf}$ & 0,361 & $\underline{0,931}$ & $-0,475$ \\
\hline 52 & Высота орбиты & $-0,008$ & $-0,252$ & $-0,037$ \\
\hline \multicolumn{2}{|c|}{ Доля в общей дисперсии (\%) } & 46,800 & 10,854 & 10,262 \\
\hline
\end{tabular}




\section{ИНФОРМАЦИЯ ОБ АВТОРАХ}

Акопян Нюра Геворковна, кандидат исторических наук, старший научный сотрудник Института археологии и этнографии НАН Республики Армении, г. Ереван, Армения

Жамкочян Агавни Сизефриевна, кандидат исторических наук, старший научный сотрудник Института археологии и этнографии НАН Республики Армении, г. Ереван, Армения

Худавердян Анаит Юрьевна, кандидат исторических наук, старший научный сотрудник Института археологии и этнографии НАН Республики Армении, г. Ереван, Армения

\section{INFORMATION ABOUT THE AUTHORS}

Nyura G. Hakopyan, Candidate of Historical Sciences, Senior Researcher at the Institute of Archeology and Ethnography of the National Academy of Sciences of the Republic of Armenia, Yerevan, Armenia

Agavni S. Zhamkochyan, Candidate of Historical Sciences, Senior Researcher at the Institute of Archeology and Ethnography of the National Academy of Sciences of the Republic of Armenia, Yerevan, Armenia

Anahit Yu. Khudaverdyan, Candidate of Historical Sciences, Senior Researcher at the Institute of Archeology and Ethnography of the National Academy of Sciences of the Republic of Armenia, Yerevan, Armenia 